\title{
Measuring and modeling mercury in the atmosphere: a critical review
}

\author{
M. S. Gustin ${ }^{1}$, H. M. Amos ${ }^{2}$, J. Huang ${ }^{1}$, M. B. Miller ${ }^{1}$, and K. Heidecorn ${ }^{1}$ \\ ${ }^{1}$ Department of Natural Resources and Environmental Science, University of Nevada-Reno, Reno, NV, 89557, USA \\ ${ }^{2}$ Department of Environmental Health, Harvard School of Public Health, Boston, MA, 02115, USA
}

Correspondence to: M. S. Gustin (mgustin@cabnr.unr.edu)

Received: 9 January 2015 - Published in Atmos. Chem. Phys. Discuss.: 10 February 2015

Revised: 9 April 2015 - Accepted: 4 May 2015 - Published: 26 May 2015

\begin{abstract}
Mercury $(\mathrm{Hg})$ is a global health concern due to its toxicity and ubiquitous presence in the environment. Here we review current methods for measuring the forms of $\mathrm{Hg}$ in the atmosphere and models used to interpret these data. There are three operationally defined forms of atmospheric $\mathrm{Hg}$ : gaseous elemental mercury (GEM), gaseous oxidized mercury (GOM), and particulate bound mercury (PBM). There is relative confidence in GEM measurements (collection on a gold surface), but GOM (collection on potassium chloride $(\mathrm{KCl})$-coated denuder) and PBM (collected using various methods) are less well understood. Field and laboratory investigations suggest the methods to measure GOM and PBM are impacted by analytical interferences that vary with environmental setting (e.g., ozone, relative humidity), and GOM concentrations measured by the $\mathrm{KCl}$-coated denuder can be too low by a factor of 1.6 to 12 depending on the chemical composition of GOM. The composition of $\mathrm{GOM}$ (e.g., $\mathrm{HgBr}_{2}, \mathrm{HgCl}_{2}, \mathrm{HgBrOH}$ ) varies across space and time. This has important implications for refining existing measurement methods and developing new ones, model/measurement comparisons, model development, and assessing trends. Unclear features of previously published data may now be re-examined and possibly explained, which is demonstrated through a case study. Priorities for future research include identification of GOM compounds in ambient air and development of information on their chemical and physical properties and GOM and PBM calibration systems. With this information, identification of redox mechanisms and associated rate coefficients may be developed.
\end{abstract}

\section{Introduction}

The Minamata Convention for mercury $(\mathrm{Hg})$ has been signed by more than 120 nations and is now being ratified. The primary objective of the convention is to "protect human health and the environment from anthropogenic emissions and releases of mercury and mercury compounds" (UNEP Minamata Convention, 2014). A key challenge for $\mathrm{Hg}$ researchers is developing linkages between $\mathrm{Hg}$ in the atmosphere, deposition, and ecosystem contamination (Pirrone et al., 2013). Here we review where the science on measuring and modeling atmospheric $\mathrm{Hg}$ currently stands and offer suggestions for future research directions that will both advance understanding of $\mathrm{Hg}$ cycling in and between environmental reservoirs and better serve the needs of the convention.

Although the atmosphere is a relatively minor reservoir of Hg compared to oceans or soils, it is an important pathway by which $\mathrm{Hg}$ is distributed globally over short timescales $(\leq 1$ year). Atmospheric deposition represents the major pathway of $\mathrm{Hg}$ input to terrestrial and aquatic ecosystems outside areas of direct contamination. A variety of environmental archives, including remote lake sediments, ombrotrophic peat bogs, glacial ice, and tree rings, suggests $\mathrm{Hg}$ inputs to the atmosphere have increased several fold in the last 150 years (cf. Engstrom et al., 2014; Schuster et al., 2002; Wright et al., 2014a). Measured concentrations of atmospheric $\mathrm{Hg}$ have been declining over the last $\sim 15$ years (Slemr et al., 2011; Cole and Steffen, 2010; Soerensen et al., 2012; Cole and Steffen, 2010; Cole et al., 2014), despite inventories suggesting global anthropogenic emissions have been relatively flat or increasing (AMAP/UNEP, 2013). This conundrum has challenged our understanding of $\mathrm{Hg}$ cycling 
and emissions, and underscores the need for continued atmospheric Hg monitoring.

Measuring the forms of $\mathrm{Hg}$ in the atmosphere is difficult. Mixing ratios are at low parts per quadrillion by volume $\left(\mathrm{ng} \mathrm{m}^{-3}\right.$ and $\mathrm{pg} \mathrm{m}^{-3}$ ). Atmospheric $\mathrm{Hg}$ is operationally defined as gaseous elemental $\mathrm{Hg}$ (GEM), gaseous oxidized $\mathrm{Hg}$ (GOM), and particulate bound $\mathrm{Hg}$ (PBM) less than $2.5 \mu \mathrm{m}$ in diameter (Lindberg et al., 2007; Schroeder and Munthe, 1998; Landis et al., 2002). GOM can be present as different forms (Huang et al., 2013, 2015). GOM and PBM have complex fundamental physiochemical properties. Because of the complexity, recent work has combined GOM and PBM concentrations as measured by the Tekran ${ }^{\circledR}$ system and defined this as reactive $\mathrm{Hg}(\mathrm{RM}=\mathrm{GOM}+\mathrm{PBM})$ (cf. Rutter and Schauer, 2007a, b; Gustin et al., 2013; Weiss-Penzias et al., 2015). Previously it was thought that GEM was 95-99\% of $\mathrm{Hg}$ in the atmosphere (cf. Schroeder and Munthe, 1998). Recent work is pointing towards GOM being $25 \%$ of total $\mathrm{Hg}$ in the boundary layer (see the discussion below). In the Arctic, up to $100 \%$ conversion of GEM to GOM has been observed (Steffen et al., 2014, 2015). In addition, it has been demonstrated that there are different GOM compounds in the air (Huang et al., 2013, 2015).

Here we review current methods for measuring the forms of $\mathrm{Hg}$ in the atmosphere and models used to interpret these data. The advantages and limitations of each measurement method are discussed, and a narrative is provided on how we have arrived at our current understanding of the limitations. The number of models that have developed the capacity to simulate atmospheric $\mathrm{Hg}$ has multiplied in the last decade. We review major gains in $\mathrm{Hg}$ science gleaned from the use of measurements and models together, as well as key open questions. We conclude with a discussion of outstanding problems facing measurement and modeling communities.

\section{Methods for measuring atmospheric $\mathrm{Hg}$}

\subsection{Atmospheric mercury basics}

Mercury is typically detected by atomic absorption (AAS) or atomic fluorescence spectroscopy (AFS). In nearly all cases, $\mathrm{Hg}$ forms are pre-concentrated on gold-coated surfaces because the sensitivity of AAS and AFS are, with the exception of laser and Zeeman AAS techniques, not sufficient for direct measurements of $\mathrm{Hg}$ at ambient concentrations. GOM and PBM are converted to GEM by thermal desorption from the gold surfaces. Gold is the most frequently used and best-studied pre-concentration material for $\mathrm{Hg}$ but can become passivated (Huang et al., 2014; Landis et al., 2002). Currently, the Tekran ${ }^{\circledR} 2537 / 1130 / 1135$ system is the most widely adopted method for measurement of atmospheric $\mathrm{Hg}$, and this instrument has been incorporated into monitoring networks, such as the Canadian Mercury Network (CAMNet), Atmospheric Mercury Network (AMNet), and Global
Mercury Observation System (GMOS). Alternate measurement methods have been developed, but are currently operated on a limited scale.

An AAS or AFS instrument combined with a pre-concentration on a gold adsorber with an inline pyrolyzer will provide total gaseous mercury $(\mathrm{TGM}=\mathrm{GEM}+\mathrm{GOM})$ or total atmospheric mercury $(\mathrm{TAM}=\mathrm{GEM}+\mathrm{GOM}+\mathrm{PBM})$. Since $\mathrm{GOM}$ is adhesive, sampling lines are often heated and should be kept short in length to prevent wall loss.

GOM and PBM are in temperature-dependent equilibrium (Rutter and Schauer, 2007b; Amos et al., 2012). Specific PBM sampling has to take account of this, in addition to the usual precautions to prevent size-dependent particle losses. Since it is difficult to achieve separation of PBM and GOM without disturbing the equilibrium, RM is a more accurate measurement to use. In addition, due to lack of capture of GOM by the denuder and collection on the PBM unit (Gustin et al., 2013), discussion of RM is more appropriate.

\subsection{Active automated systems}

\subsubsection{Tekran $^{\circledR}$ system}

The Tekran ${ }^{\circledR}$ 2537/1130/1135 system has been widely used to measure atmospheric $\mathrm{Hg}$ for the past $\sim 15$ years (Landis et al., 2002). The Tekran ${ }^{\circledR} 2537$ module measures TGM or GEM in $\mathrm{ng} \mathrm{m}^{-3}$ and was the first component to be developed. The 1130 and 1135 components were added to this system to measure GOM and PBM in $\mathrm{pg} \mathrm{m}^{-3}$ (Landis et al., 2002), respectively. The instrument pulls air through an elutriator that is heated to $50^{\circ} \mathrm{C}$ and removes particles $>2.5 \mu \mathrm{m}$, depending on the flow rate (Lyman et al., 2007). This particle size cut is necessary to keep larger particles from depositing on the denuder. GOM is collected on a potassium chloride $(\mathrm{KCl})$ coated denuder, and PBM on a column of quartz chips and a quartz filter. Air passes through $10 \mathrm{~m}$ of heated line with a soda lime trap and Teflon filter at the 2537 inlet and then into the 2537 where GEM is collected on a gold trap. It is not known whether the soda lime trap captures and retains GOM. GOM $\left(500^{\circ} \mathrm{C}\right)$ and PBM $\left(800^{\circ} \mathrm{C}\right)$ are thermally desorbed from their collection surfaces, loaded on the gold traps, and quantified as GEM (gold traps are heated to $350^{\circ} \mathrm{C}$ ) by cold vapor atomic fluorescence spectrometry (CVAFS). Although the particle cut inlet, coated annular denuder, particle filtration device, and heated line are all held at constant temperatures $\left(50^{\circ} \mathrm{C}\right)$ when sampling, there are temperature drops within the sampling line and GOM may be lost to the walls (Gustin et al., 2013). Recent work has shown that heating of the inlet to $100^{\circ} \mathrm{C}$ improves GOM collection (Huang and Gustin, 2015a).

This instrument has high temporal resolution, low limit of detection, and established quality assurance / quality control protocols (Table 1). The CAMNet and AMNet developed best management practices for this instrument (Steffen et al., 
Table 1. Pros and cons of automated and integrative methods used to make $\mathrm{Hg}$ measurements.

\begin{tabular}{|c|c|c|c|c|}
\hline & $\begin{array}{l}\mathrm{Hg} \text { form measured/detection } \\
\text { limit }\end{array}$ & Pros & Cons & Suggestion/comments \\
\hline \multicolumn{5}{|l|}{ Automated } \\
\hline $\begin{array}{l}\text { Tekran } 2537 \text { gold } \\
\text { traps }\end{array}$ & $\begin{array}{l}\text { GEM or TGM; } \\
0.5 \mathrm{ng} \mathrm{m}^{-3} \text { ambient air }\end{array}$ & $\begin{array}{l}\text { Low detection limit, } \\
2.5 \text { to } 5 \mathrm{~min} \text { resolu- } \\
\text { tion; there is a calibra- } \\
\text { tion source, standard- } \\
\text { ized by AMNet and } \\
\text { CAMNet (cf. Prestbo } \\
\text { and Gay, 2009) }\end{array}$ & $\begin{array}{l}\text { Inlet configuration } \\
\text { will impact whether } \\
\text { measuring GEM or } \\
\text { TGM; } \\
\text { requires fairly trained } \\
\text { technicians, stable } \\
\text { electrical source, reg- } \\
\text { ular calibration and } \\
\text { checks }\end{array}$ & $\begin{array}{l}\text { Suggest using a pyrolyzer at the } \\
\text { inlet if TGM measurement is de- } \\
\text { sired }\end{array}$ \\
\hline $\begin{array}{l}\text { Tekran } 1130 \mathrm{KCl} \\
\text { denuder }\end{array}$ & $\begin{array}{l}\text { GOM; } \\
1 \mathrm{pg} \mathrm{m}^{-3}\end{array}$ & $\begin{array}{l}\text { Good time resolution } \\
\text { ( } 1 \text { to } 2 \mathrm{~h})\end{array}$ & $\begin{array}{l}\text { No calibration source; } \\
\text { coating denuders needs } \\
\text { to be done by one oper- } \\
\text { ator; does not measure } \\
\text { all the GOM in air }\end{array}$ & $\begin{array}{l}\text { New method needs to be devel- } \\
\text { oped that measures all forms in } \\
\text { air and is not impacted by relative } \\
\text { humidity and ozone; a different } \\
\text { denuder coating would be useful }\end{array}$ \\
\hline $\begin{array}{l}\text { Tekran } 1135 \text { quartz } \\
\text { filter and chips }\end{array}$ & $\begin{array}{l}\text { PBM; } \\
1 \mathrm{pg} \mathrm{m}^{-3}\end{array}$ & $\begin{array}{l}\text { Good time resolution } \\
\text { ( } 1 \text { to } 2 \mathrm{~h})\end{array}$ & $\begin{array}{l}\text { Positive artifact due to } \\
\text { measurement of GOM } \\
\text { that passes through the } \\
\text { denuder; not all PBM } \\
\text { is measured due to se- } \\
\text { lect grain size capture }\end{array}$ & $\begin{array}{l}\text { Filter method may be best and } \\
\text { suggest using cation exchange } \\
\text { membranes }\end{array}$ \\
\hline Lumex & $\begin{array}{l}\text { GEM or TGM; } \\
\text { in liquids, solids, air; } \\
1 \mathrm{ng} \mathrm{m}^{-3}\end{array}$ & $\begin{array}{l}\text { Good time resolution } \\
\text { (seconds); } \\
\text { field portable; } \\
\text { allows for measure- } \\
\text { ment of } \mathrm{Hg} \text { concentra- } \\
\text { tions in environmental } \\
\text { media in the field }\end{array}$ & $\begin{array}{l}\text { Not calibrated at low } \\
\text { air concentrations }\end{array}$ & Good for industrial applications \\
\hline Gardis & $\begin{array}{l}\text { GEM or TGM; } \\
0.5 \mathrm{ng} \mathrm{m}^{-3}\end{array}$ & $\begin{array}{l}\text { Good time resolution } \\
(2.5 \mathrm{~min})\end{array}$ & $\begin{array}{l}\text { Requires trained oper- } \\
\text { ators }\end{array}$ & \\
\hline DOHGS & $\begin{array}{l}\text { GEM and TGM; } \\
80 \mathrm{pg} \mathrm{m}^{-3}\end{array}$ & $\begin{array}{l}\text { Good time resolution } \\
(2.5 \mathrm{~min})\end{array}$ & $\begin{array}{l}\text { Requires highly } \\
\text { trained operators and } \\
\text { stable environment }\end{array}$ & Useful as a research instrument \\
\hline Laser & GEM & $\begin{array}{l}\text { Fast time resolution } \\
\text { (seconds) }\end{array}$ & $\begin{array}{l}\text { Requires highly } \\
\text { trained operators and a } \\
\text { stable environment; } \\
\text { cannot quantify GOM }\end{array}$ & Useful as research instrument \\
\hline
\end{tabular}

\begin{tabular}{|c|c|c|c|c|}
\hline \multicolumn{5}{|l|}{$\begin{array}{l}\text { Integrated } \\
\text { measurements }\end{array}$} \\
\hline $\begin{array}{l}\text { GEM sampler } \\
\text { activated carbon }\end{array}$ & $\begin{array}{l}\text { GEM or TGM; } \\
10-80 \mathrm{pg} \mathrm{m}^{-3}\end{array}$ & Easy operation & Long time resolution & $\begin{array}{l}\text { Good for areas with high } \\
\text { concentration gradients }\end{array}$ \\
\hline GOM mist chamber & $\begin{array}{l}\text { GOM; } \\
\text { Blank: } 20-50 \mathrm{pg}\end{array}$ & & $\begin{array}{l}\text { Complicated } \\
\text { operation; } \\
\text { needs acidified solu- } \\
\text { tion }\end{array}$ & $\begin{array}{l}\text { Useful as a research instrument; } \\
\text { needs to be re-evaluated }\end{array}$ \\
\hline $\begin{array}{l}\text { GOM passive } \\
\text { sampler } \\
\text { concentration }\end{array}$ & $\begin{array}{l}\text { GOM; } \\
2.3-5 \mathrm{ng} \mathrm{m}^{-3}\end{array}$ & Easy operation & Long time resolution & Needs a new design \\
\hline $\begin{array}{l}\text { GOM passive } \\
\text { sampler deposition }\end{array}$ & $\begin{array}{l}\text { GOM; } \\
\text { probably PBM; } \\
0.02-0.24 \mathrm{ng} \mathrm{m}^{-2} \mathrm{~h}^{-1}\end{array}$ & $\begin{array}{l}\text { Easy operation; } \\
\text { real } \mathrm{Hg} \text { loading to } \\
\text { ecosystem }\end{array}$ & Long time resolution & Good for worldwide network \\
\hline $\begin{array}{l}\text { Direct particulate } \\
\text { matter sampler } \\
\text { measurement }\end{array}$ & $\begin{array}{l}\text { PBM; } \\
\text { probably GOM }\end{array}$ & Easy operation & $\begin{array}{l}\text { Artifacts from GOM } \\
\text { partition; choice of fil- } \\
\text { ters important to con- } \\
\text { sider and length of } \\
\text { sampling line }\end{array}$ & \\
\hline UNR active system & $\begin{array}{l}\text { GOM; } \\
\sim 30 \mathrm{pg} \mathrm{m}^{-3}\end{array}$ & $\begin{array}{l}\text { Easy operation; } \\
\text { for quantifying GOM } \\
\text { and trying to under- } \\
\text { stand the chemical } \\
\text { forms in air }\end{array}$ & $\begin{array}{l}\text { Potentially some PBM } \\
\text { measured }\end{array}$ & $\begin{array}{l}\text { Good for networks, and it could } \\
\text { be used to help calibrate mea- } \\
\text { surements made by the Tekran } \\
\text { system }\end{array}$ \\
\hline
\end{tabular}


2012; Gay et al., 2013). Co-located GEM measurement can deviate by 20 to $30 \%$ (Aas, 2006; Gustin et al., 2013). Lyman et al. (2007; Supplement) found that TGM could vary by $7.0 \pm 5.3 \%$. There are no calibration standards for GOM, breakthrough can result in collection on the PBM filter, and collection efficiencies for GOM and PBM are uncertain (cf. Gustin and Jaffe, 2010; Huang et al., 2013; Talbot et al., 2011).

\subsubsection{Lumex}

Lumex RA-915 and Lumex 915+ (Lumex, St. Petersburg, Russia) units measure GEM and TGM, respectively, with a reported detection limit of $\sim 1 \mathrm{ng} \mathrm{m}^{-3}$ for measurements in air. If averaged over the sampling time of the GEM measurement by the Tekran ${ }^{\circledR}$ system $(5 \mathrm{~min})$, a detection limit of a few tenths of $\mathrm{ng} \mathrm{m}^{-3}$ can be achieved. The Lumex uses Zeeman atomic absorption spectrometry with Zeeman background correction. In this instrument, a Hg vapor lamp sits in a magnetic field and generates a $254 \mathrm{~nm}$ light wavelength split into three polarized light fields. A photodetector detects light in one field within the $\mathrm{Hg}$ absorption wavelength $254 \mathrm{~nm}$ and another lying outside of this wavelength. The signals from both fields are equal when $\mathrm{Hg}$ is not present (for details see Sholupov et al., 2004). The instrument can be periodically calibrated using a permeation source such as used for internal calibration of the Tekran ${ }^{\circledR}$ instruments. This is not available commercially (F. Slemr, personal communication, 2015).

\subsubsection{Gardis}

The Gardis Hg analyzer has two gold traps, a concentrating and analytical trap, and measures $\mathrm{Hg}$ using CVAAS (Institute of Physics, Lithuania). Having two gold traps might reduce some interferences, such as passivation. This instrument will measure GEM, TGM, or TAM depending on inlet configuration and was developed in 1995 by Urba et al. (1995). In a field comparison, concentrations were similar to that measured by the Tekran ${ }^{\circledR} 2537$ (Ebinghaus et al., 1999). This unit has had limited use and a reported detection limit of $0.5 \mathrm{ng} \mathrm{m}^{-3}$ (Table 1).

\subsubsection{University of Houston Mercury system (UHMERC)}

UHMERC was designed for measuring GEM and TGM (Talbot et al., 2008). This instrument uses two Tekran ${ }^{\circledR}$ systems that are slightly modified (gold trap heated to $460^{\circ} \mathrm{C}$ ). The inlet to the instrument measuring GEM consists of a Teflon filter to remove fine particles $(<2 \mu \mathrm{m})$ with a molecular sieve trap immediately after to remove GOM (Gustin et al., 2013).

\subsubsection{Detector for oxidized Hg species (DOHGS)}

The DOHGS instrument measures TGM and GEM using two Tekran ${ }^{\circledR} 2537$ units. The difference between these measurements is interpreted as RM. The original instrument is described in Swartzendruber et al. (2009), and subsequent modifications to the system can be found in Ambrose et al. (2013) and Lyman and Jaffe (2012). The measurement of GEM requires that GOM and PBM be selectively removed from the airstream. In early versions, only GOM was removed using a KCl-coated denuder. This led to the discovery of a discrepancy between GOM collected on KCl-coated denuders and that measured by the difference method (Swartzendruber et al., 2009). The GOM removal method was changed to quartz chips maintained at $650^{\circ} \mathrm{C}$ as a pyrolyzer to measure TGM and then quartz wool (Lyman and Jaffe, 2012; Ambrose et al., 2013). More recently a cation-exchange membrane filter has been used to remove RM compounds.

The method detection limit for RM is $\sim 80 \mathrm{pg} \mathrm{m}^{-3}$ (Ambrose et al., 2013; Table 1). Extensive testing has been conducted on the DOHGS using calibration sources of $\mathrm{Hg}^{0}$, $\mathrm{HgBr}_{2}$, and $\mathrm{HgCl}_{2}$. Improving the sensitivity of the underlying CVAFS systems would enable more routine operation of this instrument.

\subsubsection{Laser systems}

Two laser systems have been developed for measurement of GEM (Faïn et al., 2010; Pierce et al., 2013; Bauer et al., 2002, $2010,2014)$. One is a cavity ring-down system, and the other operates on the principle of laser-induced fluorescence. Both are calibrated using Tekran ${ }^{\circledR}$ data. These do not currently have the ability to measure GOM or PBM. If GOM and/or PBM were to be measured, they must be converted to GEM first. The cavity ring-down instrument has interferences with ozone $\left(\mathrm{O}_{3}\right)$ (Faïn et al., 2010; Pierce et al., 2013). Laser systems are best applied in laboratory settings given the current sensitivity, need for a consistent electrical supply, and large electrical power use.

During the Reno Atmospheric Mercury Intercomparison eXperiment, the laser-induced fluorescence system operated by University of Miami successfully sampled on 18 days, typically for between 4 and $6 \mathrm{~h}$ a day. The longest period of continuous sampling lasted for $26 \mathrm{~h}$. During RAMIX they sampled directly from the manifold and, in addition, at the end of the campaign sampled ambient air independently, including true in situ sampling on the roof of their mobile lab. They also attempted to measure GOM by pyrolyzing the sample air and measuring the difference between $\mathrm{Hg}(0)$ and TGM (Bauer et al., 2014; A. Hynes, personal communication, 2015). 


\subsection{Active manual samplers}

Here we briefly review manual sampling methods for GEM/TGM, GOM, and PBM. Manual samplers collect over a specific amount of time, and then the samples collected need to be analyzed using an alternate method. In contrast, automated samplers provide short time (seconds to minutes) resolution measurements and do not need measurements by an alternate method.

\subsubsection{Mist chamber method for RM}

Stratton and Lindberg (1995), Lindberg and Stratton (1998), Lindberg et al. (2000), and Stratton et al. (2001) described development of a mist chamber for measurement of GOM (termed RGM then). The principle of operation includes pulling air at a high flow rate (15 to $20 \mathrm{Lpm})$ through a fine mist aerosol made of water, $\mathrm{NaCl}$, and $\mathrm{HCl}$. GOM and PBM accumulate in droplets captured on a membrane. This liquid drains into a chamber and is collected, stored in vials, and analyzed using EPA Method 1631 (EPA Method 1631, 2013).

Sheu and Mason (2001) compared denuders, mist chambers, and a filter pack method for GOM (see the Supplement for details). They showed GOM concentrations in Maryland could be up to $500 \mathrm{pg} \mathrm{m}^{-3}$ and that GOM could be up to $30 \%$ of the TGM. Reported daytime concentrations measured by the mist chamber were significantly higher (20 to $700 \mathrm{pg} \mathrm{m}^{-3}$ ) than the $\mathrm{KCl}$-coated denuder (20 to $70 \mathrm{pg} \mathrm{m}^{-3}$ ).

\subsubsection{UNR active system for GOM}

The UNR active system measures ambient GOM concentrations and identifies GOM compounds. It consists of a six-port system each with two in-series Teflon filter holders. Three of the filter holders house nylon membranes and three-cation exchange membranes. Air is pulled using a vacuum pressure pump through the membranes with flow regulated by a mass flow controller at a rate of $\sim 1 \mathrm{Lpm}$. (Huang et al., 2013). This unit is not thought to measure PBM as configured (Huang et al., 2013, 2015).

Cation exchange membranes are analyzed using EPA Method 1631 (EPA Method 1631, 2013) to quantify GOM concentrations. Nylon membranes are thermally desorbed to determine compounds present in the air (Huang et al., 2013, 2015). This method may not collect all GOM compounds (Wright et al., 2014b; Huang et al., 2014; Huang and Gustin, $2015 b)$. The nylon membrane is influenced by relative humidity (RH) (Huang et al., 2013; Huang and Gustin, 2015a). A summary of some advances presented in Huang and Gustin (2015b) associated with this method are described in the Supplement. The active system is currently limited to a resolution of 1 to 2 weeks.

\subsubsection{Active manual systems for PBM/RM}

Teflon, glass-fiber, and quartz filters have been used in openfaced filter packs, cascade impactors, and Micro-Orifice Uniform Deposition Impactors ${ }^{\mathrm{TM}}$ (MOUDIs) to measure atmospheric PBM concentrations (Keeler et al., 1995; Wang et al., 2013; Talbot et al., 2011; Engle et al., 2008; Rutter et al., 2008). PBM will vary depending on the chemistry of the aerosol, the atmosphere, and GOM chemistry along with physical conditions of the atmosphere, such as temperature and relative humidity. PBM measurements will collect some GOM and will be impacted by the filter material, flow rate, and inlet configuration.

\subsection{Passive samplers}

Passive samplers may be biotic (i.e., mosses, lichens, plant leaves) or abiotic surfaces (membranes, water). Huang et al. (2014) recently reviewed passive sampling methods for atmospheric $\mathrm{Hg}$.

\subsubsection{Total gaseous mercury}

The method developed by W. Zhang et al. (2012) used an abiotic passive sampler with sulfate-impregnated carbon contained in an axial sampler. Activated carbon was investigated as a sampling material for $\mathrm{Hg}$ by Lindberg and Turner (1977), Lindberg et al. (1979), and Lindberg (1980). Other materials that have been applied include silver wires, gold-coated plates, and gold plugs (Gustin et al., 2011; Skov et al., 2007; Huang et al., 2014). Sulfate-impregnated carbon is effective because it retains atmospheric $\mathrm{Hg}$, has a high sorption capacity, and will not become passivated over time (cf. Huang et al., 2014). This sampler is best applied for $\mathrm{Hg}$ measurements across significant concentration gradients (e.g., urban to rural). The sampler would need to be deployed for more than 90 days at a remote site. It is not known whether it measures TGM or GEM.

\subsubsection{Gaseous oxidized $\mathrm{Hg}$}

There are currently two types of passive samplers for GOM. These include surrogate surfaces to measure dry deposition, and a measurement of diffusive uptake as a surrogate for concentration. The most widely adopted dry deposition method uses a cation exchange membrane in a down-facing aerodynamic sampler housing ("Aerohead sampler"; Lyman et al., 2007,2009 ) and has been deployed in multiple studies (Castro et al., 2012; Sather et al., 2013, 2014; Peterson et al., 2012; Gustin et al., 2012; Wright et al., 2014b; Huang and Gustin, 2015b). Although there are limitations, such as measurement of only unidirectional flux, dry deposition models also apply a similar flux. Huang and Gustin (2015b) found that the surrogate surface better agreed with models when air concentrations measured by the box sampler and calibrated by the Tekran ${ }^{\circledR}$ system were adjusted by a factor of 3 . The 
box sampler designed by Lyman et al. (2010b) provides a means for calculating concentrations based on uptake rate. Recent work suggests the box sampler has significant wall loss $(80 \%)$ of GOM (Huang and Gustin, 2015b). Lack of calibration is a limitation for all passive samplers. The temporal resolution is coarse and samplers must be deployed for 1 to 2 weeks.

\subsection{Calibration methods}

One of the major outstanding issues is that the vast majority of GOM and PBM measurements are not calibrated (Jaffe et al., 2014). Calibration of GOM measurements has been done using manifold and chamber systems. Neither is automated or widely adopted. Coal fly ash is available as a standard for PBM, but calibrations have not been done. Laboratory chambers have been developed for calibrating and testing membranes and passive samplers (Gustin et al., 2011; Lyman et al., 2007, 2010b; Skov et al., 2007).

The UNR manifold calibration system is designed so specific $\mathrm{Hg}$ compounds can be added at different concentrations as well as $\mathrm{O}_{3}$, water vapor, and other chemical compounds. A pyrolyzer at the inlet can be used to determine concentrations of $\mathrm{Hg}$ being permeated (Huang et al., 2013). The eight-port glass manifold allows for collection of GOM on $\mathrm{KCl}$-coated denuders and different surfaces (Huang et al., 2013). A Tekran ${ }^{\circledR} 2537 / 1130$ unit at the end of the manifold is used to measure GEM and GOM concentrations. Manifold calibrations have also been performed by the University of Washington in the laboratory (Finley et al., 2013; McClure et al., 2014) and field (RAMIX; Gustin et al., 2013; Finley et al., 2013). During the RAMIX campaign, transmission efficiencies of GEM and $\mathrm{HgBr}_{2}$ were 92 and $76 \%$, respectively.

\section{Evolution of our understanding of the limitations of speciated Hg measurements}

\subsection{Are we measuring TAM, TGM, or GEM?}

Inlet configuration and local atmospheric chemistry will affect the measurement of TGM versus GEM. Limited work in dry air with uncovered lines (i.e., exposed to sunlight) indicated that the Tekran ${ }^{\circledR} 2537$ measures TGM (see the Supplement). If GOM is able to pass through the inlet to the Tekran ${ }^{\circledR} 2537$ and the gold traps are not passivated, the instrument will measure TGM (Gustin et al., 2013; Temme et al., 2002). Passivation of gold surfaces can occur (Barghigiani et al., 1991; Brosset and Iverfeldt, 1989; Gustin et al., 2011; Munthe et al., 1990; Xiao et al., 1991), and when this occurs these surfaces are no longer quantitatively collecting atmospheric Hg. Landis et al. (2002) mentioned passivation of gold traps periodically occurred right after analysis of a denuder, with recovery dropping to $50 \%$. To measure TAM requires the use of a pyrolyzer at the inlet to the sampling line to convert GOM + PBM to GEM. Field data suggest GOM can constitute up to $25 \%$ of TGM in Nevada, Florida, and Maryland (see Sects. 2.3.1, 3.2.2, 4) and up to $100 \%$ during depletion events in the Arctic (Steffen et al., 2014, 2015).

\subsection{PBM measurements and potential artifacts}

Relative to GOM and GEM, PBM measurements have received less systematic study. The Tekran ${ }^{\circledR}$ system is currently the most widely used configuration for measuring PBM. Other sampling methods tested include filter-based methods (Rutter et al., 2008; Talbot et al., 2011; Malcolm and Keeler, 2007; Kim et al., 2012). The sign and magnitude of the Tekran ${ }^{\circledR}$ measured PBM bias is presently unclear. Both high and low biases have been reported (Talbot et al., 2011; Rutter et al., 2008; Malcolm and Keeler, 2007; Gustin et al., 2013).

The particle size distribution of PBM is spatially heterogeneous and can include both fine and coarse fractions (Kim et al., 2012; Keeler et al., 1995; Malcolm and Keeler, 2007; Engle et al., 2008). The standard inlet on the Tekran ${ }^{\circledR}$ 2537/1130/1135 excludes particles larger than $2.5 \mu \mathrm{m}$ (depending on the flow rate; Lyman et al., 2010) in diameter to prevent large particles from depositing on the $\mathrm{KCl}$-coated denuder. Thus in coastal/marine, agricultural, or industrial settings with high concentrations of large particles, reported PBM concentrations represent a lower bound (Malcolm and Keeler, 2007; Kim et al., 2012; Poissant et al., 2005). Surrogate surfaces with cation exchange membranes may collect very small aerosol fractions by diffusion (Lyman et al., 2007; Huang and Gustin, 2015b).

Temperature and atmospheric composition potentially impact PBM measurements. The Tekran ${ }^{\circledR} 1135$ particulate module is maintained at $50^{\circ} \mathrm{C}$ to prevent condensation of water vapor. Based on filter experiments compared with Tekran ${ }^{\circledR}$ PBM, Rutter et al. (2008) suggested there is evaporative loss of PBM. Thermal desorption profiles using nylon membranes showed that $\mathrm{Hg}$ (II) compounds are emitted at temperatures ranging from 50 to $200^{\circ} \mathrm{C}$ (Fig. 2), depending on charges on the collection surface and the polarizability of the different $\mathrm{Hg}$ compounds (Huang et al., 2013). Lynam and Keeler (2005) observed less PBM collected on quartz filters for 12 versus $4 \mathrm{~h}$, and suggested a negative sampling artifact associated with relative humidity or reaction with gases in the air such as $\mathrm{O}_{3}$.

Breakthrough of GOM from the upstream denuder can result in inadvertent retention of GOM on the PBM collection surface resulting in biased high PBM measurement. In principal, the Tekran ${ }^{\circledR} 2537 / 1130 / 1135$ removes GOM on the $\mathrm{KCl}$-coated annual denuder and then PBM is collected downstream. Field data have shown that GOM compounds not collected by the $\mathrm{KCl}$-coated denuder can be captured by the particulate unit (Gustin et al., 2013). Quartz fiber filters used to collect PBM may also collect GOM (Rutter et al., 2007; see the Supplement for detailed example). Lyman et al. (2007) compared calculated dry deposition fluxes associated with 
coated $(\mathrm{KCl})$ and uncoated quartz fiber filters against data collected using cation-exchange membranes, both yielded significantly lower deposition fluxes. GOM breakthrough may not occur in all cases. For example, if there are temperature drops within the instrument, then GOM will deposit to the walls (Gustin et al., 2013). Because of these issues, the authors conclude it is presently more robust to interpret RM rather than PBM and GOM data separately.

\subsection{GOM: biases, interferences, and shedding light on the spatiotemporal variability of GOM compounds in air}

Based on laboratory and field studies, concentrations of GOM collected on the nylon and cation exchange membranes are higher than those collected by the Tekran ${ }^{\circledR}$ system by $60-1000 \%$ (Huang et al., 2014; Huang and Gustin, 2015a, b). Laboratory and field experiments have demonstrated the collection efficiency of $\mathrm{KCl}$-coated denuders varies with environmental conditions $\left(\mathrm{O}_{3}, \mathrm{RH}\right)$ and $\mathrm{Hg}(\mathrm{II})$ compounds present in air. Below we discuss recent laboratory experiments and field studies that have shaped our understanding of the limitations of GOM measurement methods.

\subsubsection{Ozone and relative humidity interferences}

Laboratory experiments have confirmed $\mathrm{O}_{3}$ interferences for $\mathrm{KCl}$-coated denuders and relative humidity interferences for both denuders and nylon membranes (Lyman et al., 2010a; McClure et al., 2014; Huang and Gustin, 2015b). Lyman et al. (2010a) found the collection efficiency of $\mathrm{HgCl}_{2}$ loaded on a $\mathrm{KCl}$ denuder was reduced by 3 to $37 \%$ when $\mathrm{O}_{3}$ concentrations were 6 to $100 \mathrm{ppbv}$. Lyman et al. (2010a) proposed reduction was occurring on the denuder wall:

$$
\mathrm{HgCl}_{2}+2 \mathrm{O}_{3} \rightarrow \mathrm{Hg}^{0}+2 \mathrm{O}_{2}+\mathrm{ClO} .
$$

Their results also indicated less GOM was recovered as $\mathrm{O}_{3}$ exposure time increased (10 to $26 \%$ removed from loaded denuders for $2.5 \mathrm{~min}$ and 29 to $55 \%$ for $30 \mathrm{~min}$ at $30 \mathrm{ppbv}$ ).

In experiments similar to those performed for $\mathrm{O}_{3}$, McClure et al. (2014) found $\mathrm{RH}$ had a similar effect on $\mathrm{HgBr}_{2}$ loaded on KCl-coated denuders. Huang and Gustin (2015a) permeated $\mathrm{HgBr}_{2}$ and water vapor into a Tekran ${ }^{\circledR} 2357 / 1130$ system in ambient air and found collection efficiencies dropped during the spikes of $\mathrm{RH}$, and the denuder became passivated over time.

They found the following at RH of 21 to $62 \%$ :

$\mathrm{RH}=0.63 \mathrm{GOM}$ loss $\%+18.1, r^{2}=0.49, p$ value $<0.01$.

Huang and Gustin (2015a) found a greater impact of relative humidity than $\mathrm{O}_{3}$.

\subsubsection{Variability of RM composition and concentrations}

Here we use comparisons of data collected with a variety of sampling methods to better understand atmospheric $\mathrm{Hg}$ concentrations and how measurement discrepancies vary with environmental setting (e.g., $\mathrm{RH}$ and $\mathrm{O}_{3}$ ) and $\mathrm{Hg}(\mathrm{II})$ compounds present in the ambient atmosphere. This includes data collected as part of a large study in Florida (Peterson et al., 2012; Gustin et al., 2012), the RAMIX field campaign (Gustin et al., 2013), recent comparison of KCl-coated denuder data with the UNR active system (Huang et al., 2013, 2015), and laboratory testing (Huang et al., 2013; Huang and Gustin, 2015a, b). For a historical review of additional literature see the Supplement in Gustin et al. (2013), Huang et al. (2014), and this paper.

Peterson et al. (2012) compared passive samplers and Tekran ${ }^{\circledR}$ data from three sites in Florida. The region has high $\mathrm{Hg}$ wet deposition but low GOM concentrations (on average $2-8 \mathrm{pg} \mathrm{m}^{-3}$ as measured by the Tekran ${ }^{\circledR}$ system). In general, the Aerohead or dry deposition sampling system (described above), showed higher deposition for GOM than that calculated using $\mathrm{KCl}$-coated denuder concentrations and a dry deposition model. Based on passive sampler uptake and calculated deposition velocities, Peterson et al. (2012) suggested the difference could be explained by the presence of different GOM compounds in the air (see the Supplement for additional detail). Examining the data across all seasons, using three $\mathrm{Hg}$ measurement methods, criteria pollutants, and meteorology, Gustin et al. (2012) concluded there were different GOM compounds in air that were derived from different primary sources, sources producing different oxidants, and variation across season.

Data from the RAMIX experiment also indicated the $\mathrm{KCl}$ denuder measurements were biased low through spikes of GOM $\left(\mathrm{HgBr}_{2}\right)$ into a manifold. Ambient air RM concentrations measured by the DOGHS were higher than those measured by the Tekran ${ }^{\circledR}$ system and this instrument recovered $66 \%$ of the $\mathrm{HgBr}_{2}$ spike during RAMIX (Gustin et al., 2013). The experiment also indicated RH caused the denuders to become passivated over time (Gustin et al., 2013). Spike recoveries of $\mathrm{HgBr}_{2}$ by KCl-coated denuders were 2 to 5 times lower than that measured by the DOGHS, with mean values for spikes ranging from 17 to $23 \%$ recovery. Replicate nylon membranes collected 30 to $50 \%$ more RM than the Tekran ${ }^{\circledR}$ system in ambient air. For a concise summary of the results of the RAMIX DOHGS versus Tekran ${ }^{\circledR}$ data and an explanation for a component of the atmospheric chemistry occurring see the Supplement.

Figure 1 and Table 2 show correlations between specific GOM compounds concentrations measured by the nylon and cation exchange membranes versus the $\mathrm{KCl}$-coated denuder in the Tekran ${ }^{\circledR}$ system (see Huang et al. (2013) for detail on the experimental setup). These data demonstrate different compounds have different collection efficiencies by the 

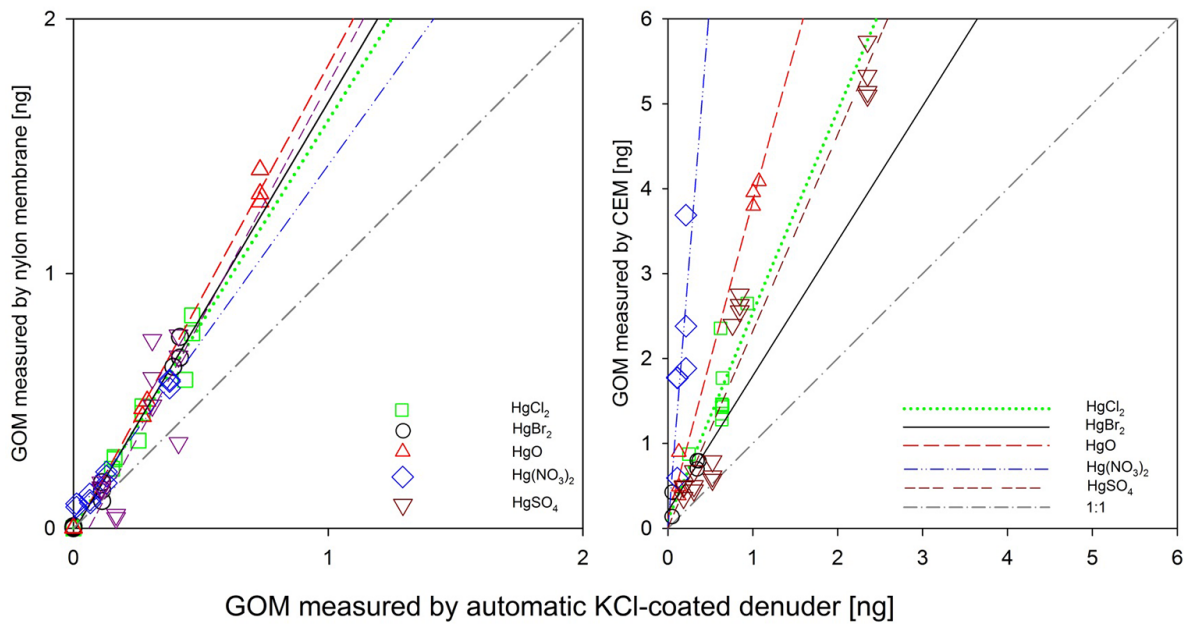

Figure 1. Correlation between GOM concentrations measured by $\mathrm{KCl}$-coated denuder and the nylon and cation exchange membranes in activated charcoal-scrubbed air. Modified from Huang et al. (2013).

Table 2. Regression equations comparing nylon membrane and cation exchange membrane measured GOM concentrations to those measured by the denuder using the UNR laboratory manifold system and charcoal-scrubbed air.

\begin{tabular}{llllll}
\hline & $\mathrm{HgCl}_{2}$ & $\mathrm{HgBr}_{2}$ & $\mathrm{HgO}$ & $\mathrm{Hg}\left(\mathrm{NO}_{3}\right)_{2}$ & $\mathrm{HgSO}_{4}$ \\
\hline Nylon membrane $(y)$ & $y=1.6 x+0.002$ & $y=1.7 x+0.01$ & $y=1.8 x+$ & $y=1.4 x+0.04$ & $y=1.9 x-0.1$ \\
KCl denuder $(x)$ & $r^{2}=0.97, n=12$ & $r^{2}=0.99, n=10$ & 0.02 & $r^{2}=0.90, n=12$ & $r^{2}=0.6, n=12$ \\
& & & $r^{2}=0.99, n=8$ & & \\
\hline Cation-exchange & $y=2.4 x+0.1$ & $y=1.6 x+0.2$ & $y=3.7 x+0.1$ & $y=12.6 x-0.02$ & $y=2.3 x+0.01$ \\
membrane $(y)$ & $r^{2}=0.58, n=9$ & $r^{2}=0.86, n=5$ & $r^{2}=0.99, n=6$ & $r^{2}=0.50, n=6$ & $r^{2}=095, n=18$ \\
KCl denuder $(x)$ & & & & & \\
\hline
\end{tabular}

denuder. Figure 1 shows the nylon membrane has equal efficiency for all $\mathrm{Hg}(\mathrm{II})$ compounds tested, and the cation exchange membrane quantitatively collects the $\mathrm{Hg}$ (II) compounds permeated. The collection efficiency of the cation exchange membrane relative to the $\mathrm{KCl}$-coated denuder in a Tekran ${ }^{\circledR} 1130$ is $\mathrm{HgBr}_{2}(1.6)>\mathrm{HgSO}_{4}(2.3)=\mathrm{HgCl}_{2}$ (2.4) $>\mathrm{HgO}(3.7)>\mathrm{Hg}\left(\mathrm{NO}_{3}\right)_{2}$ (12.6).

Huang et al. (2013) compared field data collected using the Tekran ${ }^{\circledR}$ system and the UNR active system. Cationexchange membranes measured concentrations were 1.1 to 3.7 times greater than the nylon membranes and 2 to 6 times greater than Tekran ${ }^{\circledR}$ RM values. Substantial spatial and temporal variability in the difference between the cationexchange membrane and Tekran ${ }^{\circledR} \mathrm{RM}$ values were observed. Thermal desorption profiles from the nylon membranes indicate this is explained by variability in the $\mathrm{Hg}$ (II) compounds present in air (Huang et al., 2013, 2015).

Data collected using the UNR Active System can be compared to $\mathrm{KCl}$-coated denuder measurements in different areas and used for understanding the GOM concentrations and chemistry for different areas.

\section{Case study demonstrating how we can use past measurements to move forward}

In light of the new information about interferences affecting GOM measurements, we may begin to go back and reexamine features of past data that previously could not be explained. Here we explore Weiss-Penzias et al. (2003) as a case study. They measured GEM, GOM, and PBM at Cheeka Peak Observatory (Fig. 3), Washington, USA, in the marine boundary layer and found "air of continental origin containing anthropogenic pollutants contained on average $5.3 \%$ lower GEM levels as compared with the marine boundary". GOM and PBM concentrations in continental air were very low, 0-20 and $1-4 \mathrm{pg} \mathrm{m}^{-3}$, respectively. At the time, the results were "difficult to reconcile". Now we see that the change in GEM concentrations during local anthropogenic pollution events relative to the mean of monthly marine air $\left(-60\right.$ to $\left.-270 \mathrm{pg} \mathrm{m}^{-3}\right)$ in Weiss-Penzias et al. (2003) are similar to the disparity in concentrations measured during RAMIX between the DOHGS and Tekran ${ }^{\circledR}$ RM measurement.

Retrospectively, we suggest the observed differences between the two air masses reported can be explained by dif- 


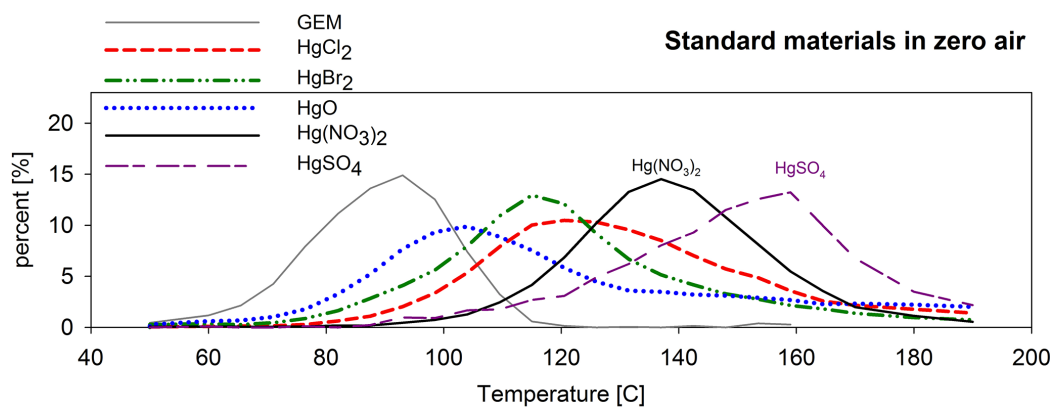

Figure 2. Thermal desorption profiles generated by permeating different $\mathrm{Hg}$ compounds. Modified from Huang et al. (2013). Percent indicates the amount released relative to the total. Profiles were developed in activated charcoal-scrubbed air. Compounds being permeated may not be the exact compound in the permeation tube, and this needs to be verified.

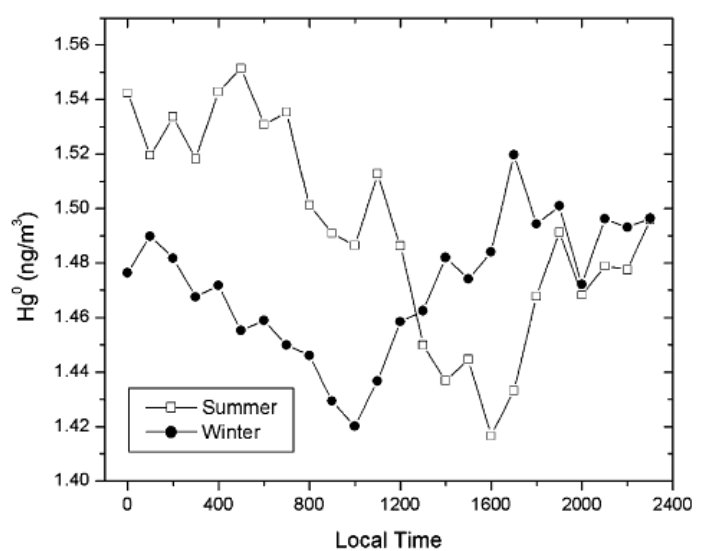

Figure 3. Figure 7 from Weiss-Penzias et al. (2003). Reprinted with permission from Weiss-Penzias et al. (2003), copyright: 1 September 2003 American Chemical Society.

ferences in the mix of oxidants and the resultant $\mathrm{Hg}$ (II) compounds formed. GOM and PBM were likely low due to lack of collection efficiency, interferences with $\mathrm{O}_{3}$, and loss in the sampling line (see the Supplement for details of sampling set up). Significantly lower GEM concentrations in the continental air are indicative of greater oxidation, which is supported by decreases in GEM concentrations coincident with $\mathrm{O}_{3}$ increases. Eastern Washington is covered by forests, which generate volatile organic compounds that could contribute to $\mathrm{O}_{3}$ and GOM formation. The marine air masses likely contained $\mathrm{HgBr}_{2}$ or $\mathrm{HgCl}_{2}$, and the continental air $\mathrm{Hg}-\mathrm{O}, \mathrm{Hg}-\mathrm{S}$, and $\mathrm{Hg}-\mathrm{N}$ compounds associated with industry, agriculture, and mobile sources. The capture efficiency of $\mathrm{HgBr}_{2}$ and $\mathrm{HgCl}_{2}$ is greater than for $\mathrm{O}, \mathrm{S}$, and $\mathrm{N}$ compounds (Fig. 1; Table 2). The case study exemplifies how we can use the loss of GEM as a means of understanding the amount of GOM present or produced in air.

\section{Advancing understanding using $\mathrm{Hg}$ measurements and models}

Here we discuss several key scientific advancements that have come from comparing models with speciated measurements, as well as the major questions left open by these studies. The number of atmospheric models capable of simulating speciated $\mathrm{Hg}$ has multiplied over the last decade (Table 3). Detailed discussion on model/measurement comparisons of RM can be found in Kos et al. (2013). Limitations and uncertainties of the models themselves have been written about at length in original research articles on model intercomparisons (Bullock et al., 2008; Pongprueksa et al., 2008; Lin et al., 2006). Fully acknowledging current limitations, there have still been huge strides made in our scientific understanding of the processes controlling GEM, GOM, and PBM cycling in the atmosphere including: marine boundary layer cycling, plume chemistry, source-receptor relationships, gas-particle partitioning, and vertical distribution.

Our understanding of speciated $\mathrm{Hg}$ cycling in the marine boundary layer (MBL) is one example of $\mathrm{Hg}$ science advancing as a result of using measurements and models in combination. GOM in the MBL has a diurnal pattern characterized by a midday peak and is depleted through deposition at night (Laurier and Mason, 2007; Laurier et al., 2003; Sprovieri et al., 2003). The use of observations and models together determined that the MBL has bromine photochemistry and was not affected by the hydroxyl $(\mathrm{OH})$ radical. This drives the midday photochemical peak in GOM concentrations in the MBL and that scavenging by sea salt was driving rapid deposition at night (Holmes et al., 2009; Selin et al., 2007; Obrist et al., 2010; Hedgecock and Pirrone, 2001, 2004; Hedgecock et al., 2003; Jaffe et al., 2005; Laurier and Masson, 2007; Laurier et al., 2003; Sprovieri et al., 2003).

Model-observation comparisons consistently suggest models overestimate GOM surface concentrations, sometimes by as much as an order of magnitude (Amos et al., 2012; W. Zhang et al., 2012; Kos et al., 2013; Holloway et al., 2012; Bieser et al., 2014). The measurement-model mis- 
Table 3. Atmospheric models with speciated mercury.

\begin{tabular}{|c|c|c|c|c|}
\hline Model name & Domain & Type & Explicit or lumped $\mathrm{Hg}(\mathrm{II})$ & References \\
\hline GRAHM & Global & 3-D, Eulerian & Explicit $\left(\mathrm{HgCl}_{2}, \mathrm{HgO}\right)$ & $\begin{array}{l}\text { Dastoor and Larocque (2004); Rya- } \\
\text { boshapko et al. (2007a, b); Dastoor et } \\
\text { al. (2008); Durnford et al. (2010); Kos et } \\
\text { al. (2013); Dastoor et al. (2014) }\end{array}$ \\
\hline GEOS-Chem & Global* $^{*}$ & 3-D, Eulerian & Bulk $\mathrm{Hg}(\mathrm{II})$ & $\begin{array}{l}\text { Selin et al. (2008); Selin and Jacob } \\
\text { (2008); Holmes et al. (2010); Corbitt et } \\
\text { al. (2011); Amos et al. (2012); Y. Zhang } \\
\text { et al. (2012); Chen et al. (2014); Kikuchi } \\
\text { et al. (2013) }\end{array}$ \\
\hline CMAQ-Hg & Continental USA & 3-D, Eulerian & Explicit $\left(\mathrm{HgCl}_{2}, \mathrm{HgO}\right)$ & $\begin{array}{l}\text { Bullock and Brehme (2002); Vijayaragha- } \\
\text { van et al. (2008); Holloway et al. (2012); } \\
\text { Bash et al. (2014) }\end{array}$ \\
\hline GLEMOS & Variable, global to regional & 3-D, Eulerian & Lumped & $\begin{array}{l}\text { Travnikov and Ryaboshapko } \\
\text { EMEP report); Travnikov (2010) }\end{array}$ \\
\hline ECHMERIT & Global & 3-D, Eulerian & $\mathrm{HgO}_{(\mathrm{g})}, \mathrm{HgCl}_{2(\mathrm{~g})}$, lumped $\mathrm{Hg}(\mathrm{II})_{(\mathrm{aq})}$ & De Simone et al. (2014); Jung et al. (2009) \\
\hline WRF-Chem & Regional & 3-D, Eulerian & Lumped & Gencarellia et al. (2014) \\
\hline MSCE-Hg-Hem & Northern Hemisphere & 3-D, Eulerian & $\mathrm{HgO}_{(\mathrm{g})}, \mathrm{HgCl}_{2(\mathrm{~g})}$, lumped $\mathrm{Hg}(\mathrm{II})_{(\mathrm{aq})}$ & $\begin{array}{l}\text { Travnikov and Ryaboshapko (2002); } \\
\text { Travnikov (2005); Travnikov and } \\
\text { Ilyin (2009) }\end{array}$ \\
\hline $\mathrm{ADOM}$ & North America, Europe & 3-D, Eulerian & $\mathrm{HgO}_{(\mathrm{g})}, \mathrm{HgCl}_{2(\mathrm{~g})}$, lumped $\mathrm{Hg}(\mathrm{II})_{(\mathrm{aq})}$ & Petersen et al. (2001) \\
\hline DEHM & Northern Hemisphere & 3-D, Eulerian & $\mathrm{HgO}_{(\mathrm{g})}, \mathrm{HgCl}_{2(\mathrm{~g})}$, lumped $\mathrm{Hg}(\mathrm{II})_{(\mathrm{aq})}$ & $\begin{array}{l}\text { Christensen et al. (2004); Skov et } \\
\text { al. (2004, EST) }\end{array}$ \\
\hline WoRM3 & Global & 2-D, multi-media & Lumped & Qureshi et al. (2011) \\
\hline PHANTAS & Arctic & box model & Detailed, explicit $\mathrm{Hg}(\mathrm{II})$ compounds & Toyota et al. (2014) \\
\hline HYSPLIT & Global & 3-D, Lagrangian & $\mathrm{HgO}_{(\mathrm{g})}, \mathrm{HgCl}_{2(\mathrm{~g})}$, lumped $\mathrm{Hg}(\mathrm{II})_{(\mathrm{aq})}$ & Cohen et al. (2004) \\
\hline TEAM & North America & 3-D, Eulerian & $\mathrm{HgO}_{(\mathrm{g})}, \mathrm{HgCl}_{2(\mathrm{~g})}$, lumped $\mathrm{Hg}(\mathrm{II})_{(\mathrm{aq})}$ & Bullock et al. $(2008,2009)$ \\
\hline CTM-Hg & Global & 3-D, Eulerian & $\mathrm{HgO}_{(\mathrm{g})}, \mathrm{HgCl}_{2(\mathrm{~g})}$, lumped $\mathrm{Hg}(\mathrm{II})_{(\mathrm{aq})}$ & $\begin{array}{l}\text { Shia et al. (1999); Seigneur et al. (2001, } \\
\text { 2003, 2004, 2006); Lohman et al. (2008) }\end{array}$ \\
\hline REMSAD & North America & 3-D, Eulerian & Explicit $\left(\mathrm{HgCl}_{2}, \mathrm{HgO}\right)$ & Bullock et al. $(2008,2009)$ \\
\hline EMAP & Europe & 3-D, Eulerian & Lumped & Syrakov et al. (1995) \\
\hline
\end{tabular}

* The standard GEOS-Chem has a global domain with the option to have a nested high-resolution simulation over North America (Zhang et al., 2012).

match is now understood as being partly explained by a low sampling bias (see Sect. 3), but this alone cannot reconcile the discrepancy. Reduction of GOM to GEM in coal-fired power plant plumes (Edgerton et al., 2006; Lohman et al., 2006) has been invoked as a possible explanation (Amos et al., 2012; W. Zhang et al., 2012; Kos et al., 2013; Holloway et al., 2012; Vijayaraghavan et al., 2008). The mechanism for in-plume reduction (IPR) remains speculative, hindering inference about how in-plume reduction may vary with coal type, control technology, or atmospheric composition. Results from recent field and laboratory data have been mixed, providing evidence for and against IPR (Tong et al., 2014; Landis et al., 2015) (Deeds et al., 2013). The speciation of anthropogenic emission inventories is also being revisited in order to reconcile model-measurement RM mismatches (Wang et al., 2014; Bieser et al., 2014). Improving our understanding of IPR and emission speciation has important implications for the efficacy of domestic regulation such as the US EPA Mercury Air Toxics Standard and for potentially attributing trends in $\mathrm{Hg}$ wet deposition over the USA (Y. Zhang et al., 2012).

Derived source-receptor relationships will also be sensitive to uncertainties in IPR and emission speciation. On the whole, $\mathrm{Hg}$ models simulate wet deposition fluxes better than surface GOM concentrations, contributing to the relatively high degree of consensus among source-receptor studies. A comparison of source-receptor studies found models agreed within $10 \%$ in terms of the attribution of total wet $\mathrm{Hg}$ deposition to a given continental region (e.g., Europe, Asia) (AMAP/UNEP, 2013; Travnikov et al., 2010). Several source-receptor studies have concluded domestic US emissions contribute $\sim 20 \%$ to total $\mathrm{Hg}$ deposition over the contiguous USA (Selin and Jacob, 2008; Corbitt et al., 2011). W. Zhang et al. (2012) found that including IPR in a model decreased the domestic contribution to wet deposition over the USA from 22 to $10 \%$.

An additional area of measurement-model study has been gas-particle partitioning of GOM and PBM. Understanding gas-particle partitioning is important because gases and particles are removed from the atmosphere by different physical processes. There is observational and laboratory evidence that gas-particle partitioning between GOM and PBM is driven by air temperature and aerosol concentrations (Rutter and Schauer, 2007a, b; Steffen et al., 2014; Rutter et al., 2008; Amos et al., 2012; Chen et al., 2014). Implementing temperature-dependent gas-particle partitioning in a global model increased simulated annual $\mathrm{Hg}$ deposition at higher latitudes (Amos et al., 2012). Aircraft observations suggest 
gas-particle partitioning also plays a major role in influencing the vertical profile of $\mathrm{Hg}$, especially in the upper troposphere/lower stratosphere (Swartzendruber et al., 2009; Lyman and Jaffe, 2012; Murphy et al., 2006). Current gasparticle partitioning relationships are derived from surface data. PBM measurements from the summit of Mt. Bachelor suggest these relationships do not capture PBM dynamics aloft (Timonen et al., 2013). Effects of aerosol composition (Rutter and Schauer, 2007b), relative humidity, or even repartitioning of RM within the Tekran ${ }^{\circledR}$ (see Sect. 3.3) could potentially contribute to this deficiency.

Oxidation also plays a central role in $\mathrm{Hg}$ cycling at the upper troposphere/lower stratosphere boundary. Comparisons against vertical aircraft profiles of TGM consistently suggest there is too little oxidation in models in the lower stratosphere (W. Zhang et al., 2012; Holmes et al., 2010). Observations show that total $\mathrm{Hg}$ is depleted in the lower stratosphere (Holmes et al., 2010; Lyman and Jaffe, 2012; Slemr et al., 2014), which is thought to be the result of rapid oxidation of $\mathrm{Hg}(0)$ to $\mathrm{Hg}(\mathrm{II})$, partitioning of $\mathrm{Hg}(\mathrm{II})$ to sulfate aerosol, and subsequent sedimentation of PBM (Lyman and Jaffe, 2012). Aircraft measurements over Washington and Tennessee, USA, found summertime GOM peaks between 2 and $4 \mathrm{~km}$ (Swartzendruber et al., 2009; Brooks et al., 2014). Modeled GOM vertical profiles over the USA have a less pronounced peak and generally place it higher (4$6 \mathrm{~km}$ ) (Bullock et al., 2008). Correctly modeling the vertical distribution of $\mathrm{Hg}$, particularly GOM and PBM, is essential for simulating deposition and hence $\mathrm{Hg}$ loading to surface ecosystems.

Chemistry remains one of the greatest uncertainties in $\mathrm{Hg}$ models. Improving measurements to determine the chemistry can help determine the mechanism(s) at play. There is still a general lack of rate coefficients and corresponding stepby-step reaction mechanisms available. The estimated tropospheric lifetime of RM against deposition and reduction is 40 days (Holmes et al., 2010), but the reduction pathway is highly uncertain (Subir et al., 2011; Pongprueska et al., 2008), and the burden of RM in the free troposphere is uncertain by at least a factor of 2 (Selin et al., 2008; De Simone et al., 2014). Improving our knowledge of the reduction and oxidation rates in the atmosphere will allow models to better capture the vertical distribution of $\mathrm{Hg}$ and in turn better simulate Hg deposition. The recent AMAP/UNEP (2013) assessment identified this as the highest priority for $\mathrm{Hg}$ models due to the importance in the $\mathrm{Hg}$ exposure pathway.

A persistent issue is the ambiguity in comparing modeled $\mathrm{Hg}$ (II) compounds to GOM and PBM, which are operationally defined. Models either have a lumped $\mathrm{Hg}$ (II) tracer or explicitly resolve individual $\mathrm{Hg}$ (II) compounds (Table 3). Since different $\mathrm{Hg}$ (II) compounds have different collection efficiencies by the $\mathrm{KCl}$ coated denuder (Fig. 1), this further confounds how to best construct a GOM-like model quantity to compare against observations. An active dialogue between experimentalists and modelers is encouraged as the commu- nity moves forward, so modelers may implement $\mathrm{Hg}$ tracers that emulate the $\mathrm{Hg}$ compounds measured.

Recent papers have used a three-fold correction factor to adjust the GOM concentrations measured by the Tekran ${ }^{\circledR}$ system to calculate dry deposition using models in the western USA and Florida (cf. Huang and Gustin, 2015a; Huang et al., 2015). Use of this correction factor is based on the discrepancy between denuder measurements in the field and cation exchange membranes dry deposition measurements and concentrations collected using the UNR active system. Weiss-Penzias et al. (2015) found the GEOS-Chem model overestimated RM/GEM by a factor of 2.8 compared to Tekran ${ }^{\circledR}$ RM/GEM, which is roughly in line with this correction factor. These field observations were collected in dry and humid conditions and at $\mathrm{O}_{3}$ concentrations typically observed in the atmosphere. Additional consideration could be based on the $\mathrm{RH}$ and $\mathrm{O}_{3}$ concentrations and the potential GOM compounds in the air.

\section{Outstanding issues}

Mercury is present in the atmosphere at $\mathrm{pg} \mathrm{m}^{-3}$ to $\mathrm{ng} \mathrm{m}^{-3}$, and the capability to measure it is a substantial analytical accomplishment. Ongoing measurements of atmospheric $\mathrm{Hg}$ will be key in evaluating the environmental benefit of regulation on behalf of the Minimata Convention.

Here we reviewed the current state of the science for measuring and modeling atmospheric $\mathrm{Hg}$ concentrations. Recent laboratory and field investigations have shown numerous artifacts and environmental interferences can affect measurement methods. Some environments such as those with low humidity and $\mathrm{O}_{3}$ may be less susceptible to sampling interferences than others. In light of new information about the limitations of sampling methods, we may revisit and better explain certain features of previous data sets and measurement-model comparison.

Fundamental research is needed on measurement methods and the atmospheric chemistry of $\mathrm{Hg}$. We need to obtain agreement between several methods for understanding the chemical forms and compounds in the air. Only through comparison of multiple calibrated measurements can results be determined to be accurate.

Identifying the chemical compounds of RM in the atmosphere is a top priority. Understanding the final oxidation products are key for resolving questions regarding $\mathrm{Hg}$ chemistry. Knowing the dominant compounds would help with the design of measurement methods and determination of deposition velocities. Thermal desorption shows promise and mass spectrometry may be a way to verify compounds.

Development of a standard, field-deployable calibration system is needed. This system should provide spikes into ambient air and allow for studying sampling efficiencies and artifacts associated with ambient air. Lack of calibration is currently a major shortcoming. 
A pyrolyzer should be used at the inlet of the 2537 if the goal is to measure TAM. The way the Tekran ${ }^{\circledR} 1130 / 1135$ system is configured to capture GOM first and then PBM is the best method to measure these two compounds. However, given the difficulty of separating GOM from PBM, we recommend interpreting the sum of RM instead of PBM alone until separation is improved.

A measurement system that collects GOM on a denuder material demonstrated to work for all compounds of GOM, and a separate measurement on a filter using a cationexchange membrane could be used for measurement of GOM and RM. Then PBM could be determined by difference. Due to negative artifacts during long sampling times measurements should be done for $<24 \mathrm{~h}$.

A new passive sampler design is needed that quantitatively determines concentrations and is calibrated. Use of a computational fluid dynamics model to help design the sampler could be one successful way forward. Passive samplers and surrogate surfaces have longer time resolution (1 day to weeks), but are relatively inexpensive and easy to operate and could provide an alternative measure of GOM concentrations and dry deposition fluxes in large-scale sampling networks once the above issues are resolved.

\section{The Supplement related to this article is available online at doi:10.5194/acp-15-5697-2015-supplement.}

Acknowledgements. This manuscript was initiated by discussions at the "Data Collection, Analysis and Application of Speciated Atmospheric Mercury" workshop coordinated by Leiming Zhang and held on 29 July 2014 in San Francisco, California. Work at UNR was supported by the National Science Foundation (Awards: 0850545, 0917934, 1102336, 1326074), the Electric Power Research Institute, and The Southern Company. We thank Dan Jaffe and Steve Lindberg for comments on an early version of this manuscript. We thank Franz Slemr for his extensive review and constructive comments, two anonymous reviewers for their comments, and Tony Hynes for providing information on his instrument that has now been included in the paper. M. S. Gustin thanks all the undergraduate students who clean glassware and process and analyze samples in the lab, for this work could not have been done without their conscientious efforts, and Michael Gustin for his continued support.

Edited by: L. Zhang

\section{References}

Aas, W. (Ed.).: Data quality 2004, quality assurance, and field comparisons, C587 EMEP/CCC-Report 4/2006, NILU, Kjeller, Norway 2006.

AMAP/UNEP: Technical Background Report for the Global Mercury Assessment 2013., Arctic Monitoring and Assessment Program, Oslo, Norway / UNEP Chemicals Branch, Geneva, Switzerland, VI, 263 pp., http://www.unep.org/PDF/ PressReleases/GlobalMercuryAssessment2013.pdf (last access: 20 May 2015), 2013.

Ambrose, J. L., Lyman, S. N., Huang, J., Gustin, M., and Jaffe, D. A.: Fast Time Resolution Oxidized Mercury Measurements with the UW Detector for Oxidized Hg Species (DOHGS) during the Reno Atmospheric Mercury Intercomparison Experiment, Environ. Sci. Technol., 47, 7285-7294, 2013.

Amos, H. M., Jacob, D. J., Holmes, C. D., Fisher, J. A., Wang, Q., Yantosca, R. M., Corbitt, E. S., Galarneau, E., Rutter, A. P., Gustin, M. S., Steffen, A., Schauer, J. J., Graydon, J. A., St Louis, V. L., Talbot, R. W., Edgerton, E. S., Zhang, Y., and Sunderland, E. M.: Gas-particle partitioning of atmospheric $\mathrm{Hg}(\mathrm{II})$ and its effect on global mercury deposition, Atmos. Chem. Phys., 12, 591-603, doi:10.5194/acp-12-591-2012, 2012.

Barghigiani, C., Ristori, T., and Cortopassi, M.: Air mercury measurement and interference of atmospheric contaminants with gold traps, Environ. Technol., 12, 935-941, 1991.

Bash, J. O., Carlton, A. G., Hutzell, W. T., and Bullock, O. R.: Regional Air Quality Model Application of the Aqueous-Phase Photo Reduction of Atmospheric Oxidized Mercury by Dicarboxylic Acids, Atmosphere, 5, 1-15, doi:10.3390/atmos5010001, 2014.

Bauer, D., Campuzano-Jost, P., and Hynes, A. J.: Rapid, ultrasensitive detection of gas phase elemental mercury under atmospheric conditions using sequential two-photon laser induced fluorescence, Environ. Monit., 4, 339-343, 2002.

Bauer, D., Swartzendruber, P. C., and Hynes, A. J.: Deployment of a compact sequential 2 Photon LIF detection system for gaseous elemental mercury at ambient levels, Geochim. Cosmochim. Ac., 74, A60-A60, 2010.

Bauer, D., Everhart, S., Remeika, J., Tatum Ernest, C., and Hynes, A. J.: Deployment of a Sequential Two-Photon Laser Induced Fluorescence Sensor for the Detection of Gaseous Elemental Mercury at Ambient Levels: Fast, Specific, Ultrasensitive Detection with Parts-Per-Quadrillion Sensitivity, Atmos. Meas. Tech., 7, 4251-4265, doi:10.5194/amt-7-4251-2014, 2014.

Bieser, J., De Simone, F., Gencarelli, C., Geyer, B., Hedgecock, I., Matthias, V., Travnikov, O., and Weigelt, A.: A diagnostic evaluation of modeled mercury wet depositions in Europe using atmospheric speciated high-resolution observations, Environ. Sci. Pollut. Res., 21, 9995-10012, doi:10.1007/s11356-014-2863-2, 2014.

Brosset, C. and Iverfeldt, A.: Interaction of solid gold surfaces with mercury in ambient air, Water Air Soil Poll., 43, 147-168, 1989.

Brooks, S., Ren, X., Cohen, M., Luke, W., Kelley, P., Artz, R., Hynes, A., Landing, W., and Martos, B.: Airborne Vertical Profiling of Mercury Speciation near Tullahoma, TN, USA, Atmosphere, 5, 557-574, 2014.

Bullock Jr., O. R. and Brehme, K. A.: Atmospheric mercury simulation using the CMAQ model: formulation description and anal- 
ysis of wet deposition results, Atmos. Environ., 36, 2135-2146, doi:10.1016/S1352-2310(02)00220-0, 2002.

Bullock, O. R., Atkinson, D., Braverman, T., Civerolo, K., Dastoor, A., Davignon, D., Ku, J. Y., Lohman, K., Myers, T. C., Park, R. J., Seigneur, C., Selin, N. E., Sistla, G., and Vijayaraghavan, K.: The North American Mercury Model Intercomparison Study (NAMMIS): Study description and modelto-model comparisons, J. Geophys. Res.-Atmos., 113, D17310, doi:10.1029/2008JD009803, 2008.

Bullock, O. R., Atkinson, D., Braverman, T., Civerolo, K., Dastoor, A., Davignon, D., Ku, J. Y., Lohman, K., Myers, T. C., Park, R. J., Seigneur, C., Selin, N. E., Sistla, G., and Vijayaraghavan, K.: An analysis of simulated wet deposition of mercury from the North American Mercury Model Intercomparison Study, J. Geophys. Res.-Atmos., 114, doi:10.1029/2008JD011224, 2009.

Castro, M. S., Moore, C., Sherwell, J., and Brooks, S. B.: Dry deposition of gaseous oxidized mercury in Western Maryland, Sci. Total Environ., 417, 232-240, 2012.

Chen, L., Wang, H. H., Liu, J. F., Tong, Y. D., Ou, L. B., Zhang, W., Hu, D., Chen, C., and Wang, X. J.: Intercontinental transport and deposition patterns of atmospheric mercury from anthropogenic emissions, Atmos. Chem. Phys., 14, 10163-10176, doi:10.5194/acp-14-10163-2014, 2014

Christensen, J. H., Brandt, J., Frohn, L. M., and Skov, H.: Modelling of Mercury in the Arctic with the Danish Eulerian Hemispheric Model, Atmos. Chem. Phys., 4, 2251-2257, doi:10.5194/acp-42251-2004, 2004.

Cohen, M., Artz, R., Draxler, R., Miller, P., Poissant, L., Niemi, D., Ratte, D., Deslauriers, M., Duval, R., Laurin, R., Slotnick, J., Nettesheim, T., and McDonald, J.: Modeling the atmospheric transport and deposition of mercury to the Great Lakes, Environ. Res., 95, 247-265, doi:10.1016/j.envres.2003.11.007, 2004.

Cole, A. S. and Steffen, A.: Trends in long-term gaseous mercury observations in the Arctic and effects of temperature and other atmospheric conditions, Atmos. Chem. Phys., 10, 4661-4672, doi:10.5194/acp-10-4661-2010, 2010.

Cole, A. S., Steffen, A., Eckley, C. S., Narayan, J., Pilote, M., Tordon, R., Graydon, J. A., St Louis, V. L., Xu, X., and Branfireun, B. A.: A Survey of Mercury in Air and Precipitation across Canada: Patterns and Trends, Atmosphere, 5, 635-668, 2014.

Corbitt, E. S., Jacob, D. J., Holmes, C. D., Streets, D. G., and Sunderland, E. M.: Global Source-Receptor Relationships for Mercury Deposition Under Present-Day and 2050 Emissions Scenarios, Environ. Sci. Technol., 45, 10477-10484, doi:10.1021/es202496y, 2011.

Dastoor, A. P. and Larocque, Y.: Global circulation of atmospheric mercury: a modelling study. Atmos. Environ., 38, 147-161, 2004.

Dastoor, A. P., and Durnford, D. A.: Arctic Ocean: Is It a Sink or a Source of Atmospheric Mercury?, Environ. Sci. Technol., 48, 1707-1717, doi:10.1021/es404473e, 2014.

Dastoor, A. P., Davignon, D., Theys, N., Van Roozendael, M., Steffen, A., and Ariya, P. A.: Modeling Dynamic Exchange of Gaseous Elemental Mercury at Polar Sunrise, Environ. Sci. Technol., 42, 5183-5188, 2008.

Deeds, D. A., Banic, C. M., Lu, J., and Daggupaty, S.: Mercury speciation in a coal-fired power plant plume: An aircraft-based study of emissions from the 3640 MW Nanticoke Generating Station, Ontario, Canada, Geophys. Res.-Atmos., 118, 4919-4935, 2013.
De Simone, F., Gencarelli, C. N., Hedgecock, I. M., and Pirrone, N.: Global atmospheric cycle of mercury: a model study on the impact of oxidation mechanisms, Environ. Sci. Poll. Res., 21, 4110-4123, doi:10.1007/s11356-013-2451-x, 2014.

Durnford, D., Dastoor, A., Figueras-Nieto, D., and Ryjkov, A.: Long range transport of mercury to the Arctic and across Canada, Atmos. Chem. Phys., 10, 6063-6086, doi:10.5194/acp-10-60632010, 2010.

Ebinghaus, R., Jennings, S. G., Schroeder, W. H., Berg, T., Donaghy, T., Guentzel, J., Kenny, C., Kock, H. H., Kvietkus, K., Landing, W., Mühleck, T., Munthe, J., Prestbo, E. M., Schneeberger, D., Slemr, F., Sommar, J., Urba, A., Wallschläger, D., and Xiao, Z.: International field intercomparison measurements of atmospheric mercury species at Mace Head, Ireland, Atmos. Environ., 33, 3063-3073, 1999.

Edgerton, E. S., Hartsell, B. E., and Jansen, J. J.: Mercury Speciation in Coal-fired Power Plant Plumes Observed at Three Surface Sites in the Southeastern U.S., Environ. Sci. Technol., 40, 4563 4570, doi:10.1021/es0515607, 2006.

Engle, M. A., Tate, M. T., Krabbenhoft, D. P., Kolker, A., Olson, M. L., Edgerton, E. S., DeWild, J. F., and McPherson, A. K.: Characterization and cycling of atmospheric mercury along the central US Gulf Coast, Appl. Geochem., 23, 419-437, 2008.

Engstrom, D. R., Fitzgerald, W. F., Cooke, C. A., Lamborg, C. H., Drevnick, P. E., Swain, E. B., Balogh, S. J., and Balcom, P. H.: Atmospheric Hg Emissions from Preindustrial Gold and Silver Extraction in the Americas: A Reevaluation from Lake-Sediment Archives, Environ. Sci. Technol., 48, 6533-6543, 2014.

EPA Method 1631: http://water.epa.gov/scitech/methods/cwa/ metals/mercury/index.cfm, last access: 27 December 2014.

Faïn, X., Moosmüller, H., and Obrist, D.: Toward real-time measurement of atmospheric mercury concentrations using cavity ring-down spectroscopy, Atmos. Chem. Phys., 10, 2879-2892, doi:10.5194/acp-10-2879-2010, 2010.

Finley, B. D., Jaffe, D. A., Call, K., Lyman, S., Gustin, M. S., Peterson, C., Miller, M., and Lyman, T.: Development, Testing, And Deployment of an Air Sampling Manifold for Spiking Elemental and Oxidized Mercury During the Reno Atmospheric Mercury Intercomparison Experiment (RAMIX), Environ. Sci. Technol., 47, 7277-7284, 2013.

Gay, D. A., Schmeltz, D., Prestbo, E., Olson, M., Sharac, T., and Tordon, R.: The Atmospheric Mercury Network: measurement and initial examination of an ongoing atmospheric mercury record across North America, Atmos. Chem. Phys., 13, 1133911349, doi:10.5194/acp-13-11339-2013, 2013.

Gustin, M. and Jaffe, D.: Reducing the Uncertainty in Measurement and Understanding of Mercury in the Atmosphere, Environ. Sci. Technol., 44, 2222-2227, 2010.

Gustin, M. S. and Lindberg, S. E.: Assessing the contribution of natural sources to the global mercury cycle: The importance of intercomparing dynamic flux measurements, Fresen. J. Anal. Chem., 366, 417-422, 2000.

Gustin, M. S., Lyman, S. N., Kilner, P., and Prestbo, E.: Development of a passive sampler for gaseous mercury, Atmos. Environ., 45, 5805-5812, 2011.

Gustin, M. S., Weiss-Penzias, P. S., and Peterson, C.: Investigating sources of gaseous oxidized mercury in dry deposition at three sites across Florida, USA, Atmos. Chem. Phys., 12, 9201-9219, doi:10.5194/acp-12-9201-2012, 2012. 
Gustin, M. S., Huang, J., Miller, M. B., Peterson, C., Jaffe, D. A., Ambrose, J., Finley, B. D., Lyman, S. N., Call, K., Talbot, R., Feddersen, D., Mao, H., and Lindberg, S. E.: Do We Understand What the Mercury Speciation Instruments Are Actually Measuring? Results of RAMIX, Environ. Sci. Technol., 47, 7295-7306, 2013.

Hedgecock, I. M. and Pirrone, N.: Mercury and photochemistry in the marine boundary layer-modeling studies suggest the in situ production of reactive gas phase mercury, Atmos. Environ., 35, 3055-3062, doi:10.1016/s1352-2310(01)00109-1, 2001.

Hedgecock, I. M. and Pirrone, N.: Chasing quicksilver: Modeling the atmospheric lifetime of $\mathrm{Hg}-(\mathrm{g})(0)$ in the marine boundary layer at various latitudes, Environ. Sci. Technol., 38, 69-76, doi:10.1021/es034623z, 2004.

Hedgecock, I. M., Pirrone, N., Sprovieri, F., and Pesenti, E.: Reactive gaseous mercury in the marine boundary layer: modelling and experimental evidence of its formation in the Mediterranean region, Atmos. Environ., 37, S41-S49, doi:10.1016/s13522310(03)00236-x, 2003.

Holloway, T., Voigt, C., Morton, J., Spak, S. N., Rutter, A. P., and Schauer, J. J.: An assessment of atmospheric mercury in the Community Multiscale Air Quality (CMAQ) model at an urban site and a rural site in the Great Lakes Region of North America, Atmos. Chem. Phys., 12, 7117-7133, doi:10.5194/acp-12-71172012, 2012.

Holmes, C. D., Jacob, D. J., Mason, R. P., and Jaffe, D. A.: Sources and deposition of reactive gaseous mercury in the marine atmosphere, Atmos. Environ., 43, 2278-2285, doi:10.1016/j.atmosenv.2009.01.051, 2009.

Holmes, C. D., Jacob, D. J., Corbitt, E. S., Mao, J., Yang, X., Talbot, R., Slemr, F.: Global atmospheric model for mercury including oxidation by bromine atoms, Atmos. Chem. Phys., 10, 1203712057, 2010, http://www.atmos-chem-phys.net/10/12037/2010/.

Huang, J. and Gustin, M. S.: Impacts of relative humidity on GOM measurements, Environ. Sci. Technol., 49, 6102-6108, doi:10.1021/acs.est.5b00098, 2015a.

Huang, J. and Gustin, M. S.: Use of passive sampling methods and models to understand sources of mercury deposition to high elevation sites in the Western United States, Environ. Sci. Technol., 49, 432-441, doi:10.1021/es502836w, 2015b.

Huang, J. Y., Miller, M. B., Weiss-Penzias, P., and Gustin, M. S.: Comparison of Gaseous Oxidized Hg Measured by KCl-Coated Denuders, and Nylon and Cation Exchange Membranes, Environ. Sci. Technol., 47, 7307-7316, 2013.

Huang, J. Y., Lyman, S. N., Hartman, J. S., and Gustin, M. S.: A review of passive sampling systems for ambient air mercury measurements, Environ. Sci.-Proc. Imp., 16, 374-392, 2014.

Huang, J., Miller, M. B., Edgerton, E., and Gustin, M. S.: Use of Criteria Pollutants, Active and Passive Mercury Sampling, and Receptor Modeling to Understanding the Chemical Forms of Gaseous Oxidized Mercury in Florida, Atmos. Chem. Phys. Discuss., 15, 12069-12105, doi:10.5194/acpd-15-12069-2015, 2015.

Jaffe, D., Prestbo, E., Swartzendruber, P., Weiss-Penzias, P., Kato, S., Takami, A., Hatakeyama, S., and Kajii, Y.: Export of atmospheric mercury from Asia, Atmos. Environ., 39, 3029-3038, doi:10.1016/j.atmosenv.2005.01.030, 2005.
Jaffe, D. A., Lyman, S., Amos, H. M., Gustin, M. S., Huang, J., Selin, N. E., Levin, L., ter Schure, A., Mason, R. P., Talbot, R., Rutter, A., Finley, B., Jaeglé, L., Shah, V., McClure, C., Ambrose, J., Gratz, L., Lindberg, S., Weiss-Penzias, P., Sheu, G.-R., Feddersen, D., Horvat, M., Dastoor, A., Hynes, A. J., Mao, H., Sonke, J. E., Slemr, F., Fisher, J. A., Ebinghaus, R., Zhang, Y., and Edwards, G.: Progress on Understanding Atmospheric Mercury Hampered by Uncertain Measurements, Environ. Sci. Technol., 48, 7204-7206, doi:10.1021/es5026432, 2014.

Keeler, G., Glinsorn, G., and Pirrone, N.: Particulate mercury in the atmosphere: Its significance, transport, transformation and sources, Water Air Soil Poll., 80, 159-168, 1995.

Kikuchi, T., Ikemoto, H., Takahashi, K., Hasome, H., and Ueda, H.: Parameterizing Soil Emission and Atmospheric OxidationReduction in a Model of the Global Biogeochemical Cycle of Mercury, Environ. Sci. Technol., 47, 12266-12274, doi:10.1021/es401105h, 2014.

Kim, P.-R., Han, Y.-J., Holsen, T. M., and Yi, S.-M.: Atmospheric particulate mercury: Concentrations and size distributions, Atmos. Environ., 61, 94-102, 2012.

Kos, G., Ryzhkov, A., Dastoor, A., Narayan, J., Steffen, A., Ariya, P. A., and Zhang, L.: Evaluation of discrepancy between measured and modelled oxidized mercury species, Atmos. Chem. Phys., 13, 4839-4863, doi:10.5194/acp-13-4839-2013, 2013.

Landis, M. S., Stevens, R. K., Schaedlich, F., and Prestbo, E. M.: Development and characterization of an annular denuder methodology for the measurement of divalent inorganic reactive gaseous mercury in ambient air, Environ. Sci. Technol., 36, 3000-3009, 2002.

Landis, M. S., Ryan, J. F., Arnout, F. H., Schure, T., and Laudal, D.: The Behavior of Mercury Emissions from a Commercial CoalFired Power Plant: The Relationship Between Stack Speciation and Near-Field Plume Measurements, Environ. Sci. Technol., 48, 13540-13548, 2015.

Laurier, F. J. G. and Mason, R. P.: Mercury concentration and speciation in the coastal and open ocean boundary layer, J. Geophys. Res., 112, D06302, doi:10.1029/2006JD007320, 2007.

Laurier, F. J. G., Mason, R. P., Whalin, L., and Kato, S.: Reactive gaseous mercury formation in the North Pacific Ocean's marine boundary layer: A potential role of halogen chemistry, J. Geophys. Res., 108, 4529, doi:10.1029/2003JD003625, 2003.

Lin, C.-J., Pongprueksa, P., Lindberg, S. E., Pehkonen, S. O., Byun, D., and Jang, C.: Scientific uncertainties in atmospheric mercury models I: Model science evaluation, Atmos. Environ., 40, 29112928, 2006.

Lindberg, S. E.: Mercury partitioning in a power plant plume and its influence on atmospheric removal mechanisms, Atmos. Environ., 14, 227-231, 1980.

Lindberg, S. E. and Stratton, W. J.: Atmospheric mercury speciation: Concentrations and behavior of reactive gaseous mercury in ambient air, Environ. Sci. Technol., 32, 49-57, 1998.

Lindberg, S. E. and Turner, R. R.: Mercury emissions from chlorine production solid waste deposits, Nature, 268, 133-136, 1977.

Lindberg, S. E., Jackson, D. R., Huckabee, J. W., Janzen, S. A., Levin, M. J., and Lund, J. R.: Atmospheric emission and plant uptake of mercury from agricultural soils near the Almaden mercury mine, J. Environ. Qual., 8, 572-578, 1979.

Lindberg, S. E., Stratton, W. J., Pai, P., and Allan, M. A.: Measurements and modeling of a water soluble gas-phase mercury 
species in ambient air, Fuel Process. Technol., 65, 143-156, 2000.

Lindberg, S. E., Bullock, R., Ebinghaus, R., Engstrom, D., Feng, X., FItzgerald, W., Pirrone, N., Prestbo, E., and Seigneur, C.: A synthesis of progress and uncertainties in attributing the sources of mercury in deposition, AMBIO, 36, 19-32, 2007.

Lohman, K., Seigneur, C., Edgerton, E., and Jansen, J.: Modeling mercury in power plant plumes, Environ. Sci. Technol., 40, 3848-3854, doi:10.1021/es051556v, 2006.

Lyman, S. N. and Jaffe, D. A.: Formation and fate of oxidized mercury in the upper troposphere and lower stratosphere, Nat. Geosci., 5, 114-117, doi:10.1038/ngeo1353, 2012.

Lyman, S. N., Jaffe, D. A., and Gustin, M. S.: Release of mercury halides from $\mathrm{KCl}$ denuders in the presence of ozone, Atmos. Chem. Phys., 10, 8197-8204, doi:10.5194/acp-10-81972010, 2010a.

Lyman, S. N., Gustin, M. S., and Prestbo, E. M.: A passive sampler for ambient gaseous oxidized mercury concentrations, Atmos. Environ., 44, 246-252, 2010b.

Lyman, S. N., Gustin, M. S., Prestbo, E. M., Kilner, P. I., Edgerton, E., and Hartsell, B.: Testing and Application of Surrogate Surfaces for Understanding Potential Gaseous Oxidized Mercury Dry Deposition, Environ. Sci. Technol., 43, 6235-6241, 2009.

Lyman, S. N., Gustin, M. S., Prestbo, E. M., and Marsik, F. J.: Estimation of dry deposition of atmospheric mercury in Nevada by direct and indirect methods, Environ. Sci. Technol., 41, 19701976, 2007.

Lyman, S. N. and Jaffe, D. A.: Formation and fate of oxidized mercury in the upper troposphere and lower stratosphere, Nat. Geosci., 5, 114-117, 2012.

Lynam, M. M. and Keeler, G. J.: Artifacts associated with the measurement of particulate mercury in an urban environment: The influence of elevated ozone concentrations, Atmos. Environ., 39, 3081-3088, 2005.

Malcolm, E. G. and Keeler, G. J.: Evidence for a sampling artifact for particulate-phase mercury in the marine atmosphere, Atmos. Environ., 41, 3352-3359, 2007.

McClure, C. D., Jaffe, D. A., and Edgerton, E. S.: Evaluation of the $\mathrm{KCl}$ Denuder Method for Gaseous Oxidized Mercury using $\mathrm{HgBr} 2$ at an In-Service AMNet Site, Environ. Sci. Technol., 48, 11437-11444, 2014.

Munthe, J., Schroeder, W. H., Xiao, Z., and Lindqvist, O.: Removal of gaseous mercury from air using a gold coated denuder, Atmos. Environ., 24, 2271-2274, 1990.

Murphy, D. M., Hudson, P. K., Thomson, D. S., Sheridan, P. J., and Wilson, J. C.: Observations of mercury-containing aerosols, Environ. Sci. Technol., 40, 316-3167, doi:10.1021/es052385x, 2006.

Obrist, D., Faïn, X., and Berger, C.: Gaseous elemental mercury emissions and $\mathrm{CO}_{2}$ respiration rates in terrestrial soils under controlled aerobic and anaerobic laboratory conditions, Sci. Total Environ., 408, 1691-1700, doi:10.1016/j.scitotenv.2009.12.008, 2010.

Petersen, G., Bloxam, R., Wong, S., Munthe, J., Kruger, O., Schmolke, S. R., and Kumar, A. V.: A comprehensive Eulerian modelling framework for airborne mercury species: model development and applications in Europe, Atmos. Environ., 35, 30633074, doi:10.1016/s1352-2310(01)00110-8, 2001.
Peterson, C., Alishahi, M., and Gustin, M. S.: Testing the use of passive sampling systems for understanding air mercury concentrations and dry deposition across Florida, USA, Sci. Total Environ., 424, 297-307, 2012.

Pierce, A., Obrist, D., Moosmüller, H., Faïn, X., and Moore, C.: Cavity ring-down spectroscopy sensor development for high-time-resolution measurements of gaseous elemental mercury in ambient air, Atmos. Meas. Tech., 6, 1477-1489, doi:10.5194/amt-6-1477-2013, 2013.

Pirrone, N., Aas, W., Cinnirella, S., Ebinghaus, R., Hedgecock, I. M., Pacyna, J., Sprovieri, F., and Sunderland, E. M.: Toward the next generation of air quality monitoring: Mercury, Atmos. Environ., 80, 599-611, 2013.

Poissant, L., Pilote, M., Beauvais, C., Constant, P., and Zhang, H. H.: A year of continuous measurements of three atmospheric mercury species (GEM, RGM and Hg-p) in southern Quebec, Canada, Atmos. Environ., 39, 1275-1287, 2005.

Pongprueksa, P., Lin, C. J., Lindberg, S. E., Jang, C., Braverman, T., Bullock, O. R., Ho, T. C., and Chu, H. W.: Scientific uncertainties in atmospheric mercury models III: Boundary and initial conditions, model grid resolution, and $\mathrm{Hg}$ (II) reduction mechanism, Atmos. Environ., 42, 1828-1845, doi:10.1016/j.atmosenv.2007.11.020, 2008.

Qureshi, A., MacLeod, M., and Hungerbuhler, K.: Quantifying uncertainties in the global mass balance of mercury, Global Biogeochem. Cy., 25, GB4012, Gb4012, doi:10.1029/2011GB004068, 2011.

Ryaboshapko, A., Bullock Jr, O. R., Christensen, J., Cohen, M., Dastoor, A., Ilyin, I., Petersen, G., Syrakov, D., Artz, R. S., Davignon, D., Draxler, R. R., and Munthe, J.: Intercomparison study of atmospheric mercury models: 1 . Comparison of models with short-term measurements, Sci. Total Environ., 376, 228 240, 2007a.

Ryaboshapko, A., Bullock Jr, O. R., Christensen, J., Cohen, M., Dastoor, A., Ilyin, I., Petersen, G., Syrakov, D., Travnikov, O., Artz, R. S., Davignon, D., Draxler, R. R., Munthe, J., and Pacyna, J.: Intercomparison study of atmospheric mercury models: 2. Modelling results vs. long-term observations and comparison of country deposition budgets, Sci. Total Environ., 377, 319-333, 2007b.

Rutter, A. P. and Schauer, J. J.: The impact of aerosol composition on the particle to gas partitioning of reactive mercury, Environ. Sci. Technol., 41, 3934-3939, doi:10.1021/es062439i, 2007a.

Rutter, A. P. and Schauer, J. J.: The effect of temperature on the gas-particle partitioning of reactive mercury in atmospheric aerosols, Atmos. Environ., 41, 8647-8657, doi:10.1016/j.atmosenv.2007.07.024, 2007b.

Rutter, A. P., Hanford, K. L., Zwers, J. T., Perillo-Nicholas, A. L., Schauer, J. J., and Olson, M. L.: Evaluation of an offline method for the analysis of atmospheric reactive gaseous mercury and particulate mercury, J. Air Waste Manag. Assoc., 58, 377-383, 2008.

Sather, M. E., Mukerjee, S., Smith, L., Mathew, J., Jackson, C., Callison, R., Scrapper, L., Hathcoat, A., Adam, J., and Keese, D.: Gaseous oxidized mercury dry deposition measurements in the Four Corners area and Eastern Oklahoma, USA, Atmos. Poll. Res., 4, 168-180, 2013.

Sather, M. E., Mukerjee, S., Allen, K. L., Sminth, L., Mathew, J., Jackson, C., Callison, R., Scrapper, L., Hathcoat, A., Adam, J., 
Keese, D., Ketcher, P., Brunette, R., Karlstrom, J., and Jagt, G. V. d. : Gaseous Oxidized Mercury Dry Deposition Measurements in the Southwestern USA: A Comparison between Texas, Eastern Oklahoma, and the Four Corners Area, Sci. World J., accession no. WOS:000334852000001, 2014.

Schroeder, W. H. and Munthe, J.: Atmospheric mercury-An overview, Atmos. Environ., 32, 809-822, 1998.

Schuster, P. F., Krabbenhoft, D. P., Naftz, D. L., Cecil, L. D., Olson, M. L., Dewild, J. F., Susong, D. D., Green, J. R., and Abbott, M. L.: Atmospheric mercury deposition during the last 270 years: A glacial ice core record of natural and anthropogenic sources, Environ. Sci. Technol., 36, 2303-2310, 2002.

Selin, N. E. and Jacob, D. J.: Seasonal and spatial patterns of mercury wet deposition in the United States: Constraints on the contribution from North American anthropogenic sources, Atmos. Environ., 42, 5193-5204, 2008.

Selin, N. E., Jacob, D. J., Park, R. J., Yantosca, R. M., Strode, S., Jaegle, L., and Jaffe, D.: Chemical cycling and deposition of atmospheric mercury: Global constraints from observations, J. Geophys. Res., 112, D02308, doi:10.1029/2006jd007450, 2007.

Seigneur, C., Karamchandani, P., Lohman, K., Vijayaraghavan, K., and Shia, R. L.: Multiscale modeling of the atmospheric fate and transport of mercury, J. Geophys. Res.-Atmos., 106, 2779527809, doi:10.1029/2000jd000273, 2001.

Seigneur, C., Karamchandani, P., Vijayaraghavan, K., Lohman, K., Shia, R. L., and Levin, L.: On the effect of spatial resolution on atmospheric mercury modeling, Sci. Total Environ., 304, 73-81, doi:10.1016/s0048-9697(02)00558-2, 2003.

Seigneur, C., Vijayaraghavan, K., Lohman, K., Karamchandani, P., and Scott, C.: Global source attribution for mercury deposition in the United States, Environ. Sci. Technol., 38, 555-569, doi:10.1021/es034109t, 2004.

Seigneur, C., Vijayaraghavan, K., and Lohman, K.: Atmospheric mercury chemistry: Sensitivity of global model simulations to chemical reactions, J. Geophys. Res., 111, doi:10.1029/2005JD006780, 2006.

Sheu, G. R. and Mason, R. P.: An examination of methods for the measurements of reactive gaseous mercury in the atmosphere, Environ. Sci. Technol., 35, 1209-1216, 2001.

Shia, R. L., Seigneur, C., Pai, P., Ko, M., and Sze, N. D.: Global simulation of atmospheric mercury concentrations and deposition fluxes, J. Geophys. Res.-Atmos., 104, 23747-23760, doi:10.1029/1999JD900354, 1999.

Sholupov, S., Pogarev, S., Ryzhov, V., Mashyanov, N., and Stroganov, A.: Zeeman atomic absorption spectrometer RA$915+$ for direct determination of mercury in air and complex matrix samples, Fuel Process. Technol., 85, 473-485, 2004.

Skov, H., Christensen, J. H., Goodsite, M. E., Heidam, N. Z., Jensen, B., Wahlin, P., and Geernaert, G.: Fate of elemental mercury in the arctic during atmospheric mercury depletion episodes and the load of atmospheric mercury to the arctic, Environ. Sci. Technol., 38, 2373-2382, doi:10.1021/es030080h, 2004.

Skov, H., Sorensen, B. T., Landis, M. S., Johnson, M. S., Sacco, P., Goodsite, M. E., Lohse, C., and Christensen, K. S.: Performance of a new diffusive sampler for atmospheric $\mathrm{Hg} 0$ determination, Environ. Chem., 4, 75-80, 2007.

Slemr, F., Brunke, E.-G., Ebinghaus, R., and Kuss, J.: Worldwide trend of atmospheric mercury since 1995, Atmos. Chem. Phys., 11, 4779-4787, doi:10.5194/acp-11-4779-2011, 2011.
Slemr, F., Weigelt, A., Ebinghaus, R., Brenninkmeijer, C., Baker, A., Schuck, T., Rauthe-Schoch, A., Riede, H., Leedham, E., Hermann, M., van Velthoven, P., Oram, D., O'Sullivan, D., Dyroff, C., Zahn, A., and Ziereis, H.: Mercury Plumes in the Global Upper Troposphere Observed during Flights with the CARIBIC Observatory from May 2005 until June 2013, Atmosphere, 5, 342369, doi:10.3390/atmos5020342, 2014.

Soerensen, A. L., Jacob, D. J., Streets, D. G., Witt, M. L. I., Ebinghaus, R., Mason, R. P., Andersson, M., and Sunderland, E. M.: Multi-decadal decline of mercury in the North Atlantic atmosphere explained by changing subsurface seawater concentrations, Geophys. Res. Lett., 39, L21810, doi:10.1029/2012GL053736, 2012.

Sprovieri, F., Pirrone, N., Gardfeldt, K., and Sommar, J.: Mercury speciation in the marine boundary layer alonga $6000 \mathrm{~km}$ cruise path around the Mediterranean Sea, AE, 37, 63-71, 2003.

Steffen, A., Scherz, T., Olson, M., Gay, D., and Blanchard, P.: A comparison of data quality control protocols for atmospheric mercury speciation measurements, Environ. Monit., 14, 752$765,2012$.

Steffen, A., Bottenheim, J., Cole, A., Ebinghaus, R., Lawson, G., and Leaitch, W. R.: Atmospheric mercury speciation and mercury in snow over time at Alert, Canada, Atmos. Chem. Phys., 14, 2219-2231, doi:10.5194/acp-14-2219-2014, 2014.

Steffen, A., Lehnherr, I., Cole, A., Ariya, P., Dastoor, A., Durnford, D., Kirk, J., and Pilote, M.: Atmospheric mercury measurements in the Canadian Arctic Part 1: A review of recent field measurements, Sci. Total Environ., 509-510, 3-15, 2015.

Stratton, W. J. and Lindberg, S. E.: Use of a refluxing mist chamber for measurements of gas phase mercury(II) species in the atmosphere, Water Air Soil Pollut., 80, 1269-1278, 1995.

Stratton, W. J., Lindberg, S. E., and Perry, C. J.: Atmospheric mercury speciation: Laboratory and field evaluation of a mist chamber method for measuring reactive gaseous mercury, Environ. Sci. Technol., 35, 170-177, 2001.

Subir, M., Ariya, P. A., and Dastoor, A. P.: A review of uncertainties in atmospheric modeling of mercury chemistry I. Uncertainties in existing kinetic parameters: Fundamental limitations and the importance of heterogeneous chemistry, Atmos. Environ., 45, 5664-5676, 2011.

Syrakov, D., Gryning, S. E., and Schiermeier, F. A. (Eds.): On a PCoriented Eulerian Multi-level model for long-term calculations of the regional sulphur deposition, Air pollution modeling and its application, XI, 21, Plenum Press, New York, 645-646, 1995.

Swartzendruber, P. C., Jaffe, D. A., and Finley, B.: Development and First Results of an Aircraft-Based, High Time Resolution Technique for Gaseous Elemental and Reactive (Oxidized) Gaseous Mercury, Environ. Sci. Technol., 43, 7484-7489, doi:10.1021/es901390t, 2009.

Talbot, R., Mao, H., Scheuer, E., Dibb, J., Avery, M., Browell, E., Sachse, G., Vay, S., Blake, D., Huey, G., and Fuelberg, H.: Factors influencing the large-scale distribution of $\mathrm{Hg}^{\circ}$ in the Mexico City area and over the North Pacific, Atmos. Chem. Phys., 8, 2103-2114, doi:10.5194/acp-8-2103-2008, 2008.

Talbot, R., Mao, H., Feddersen, D., Smith, M., Kim, S. Y., Sive, B., Haase, K., Ambrose, J., Zhou, Y., and Russo, R.: Comparison of Particulate Mercury Measured with Manual and Automated Methods, Atmosphere, 2, 1-20, 2011. 
Temme, C., Einax Jr., W., Ebinghaus, R., and Schroeder, W. H.: Measurements of Atmospheric Mercury Species at a Coastal Site in the Antarctic and over the South Atlantic Ocean during Polar Summer, Environ. Sci. Technol., 37, 22-31, 2002.

Timonen, H., Ambrose, J. L., and Jaffe, D. A.: Oxidation of elemental $\mathrm{Hg}$ in anthropogenic and marine airmasses, Atmos. Chem. Phys., 13, 2827-2836, doi:10.5194/acp-13-2827-2013, 2013.

Tong, Y. D., Eichhorst, T., Olson, M. R., Rutter, A. P., Shafer, M. M., Wang, X. J., and Schauer, J. J.: Comparison of heterogeneous photolytic reduction of $\mathrm{Hg}$ (II) in the coal fly ashes and synthetic aerosols, Atmos. Res., 138, 324-329, doi:10.1016/j.atmosres.2013.11.015, 2014.

Toyota, K., Dastoor, A. P., and Ryzhkov, A.: Air-snowpack exchange of bromine, ozone and mercury in the springtime Arctic simulated by the 1-D model PHANTAS - Part 2: Mercury and its speciation, Atmos. Chem. Phys., 14, 4135-4167, doi:10.5194/acp-14-4135-2014, 2014.

Travnikov, O.: Contribution of the intercontinental atmospheric transport to mercury pollution in the Northern Hemisphere, Atmos. Environ., 39, 7541-7548, doi:10.1016/j.atmosenv.2005.07.066, 2005.

Travnikov, O. and Ilyin, I.: The EMEP/MSC-E Mercury Modeling System, Mercury Fate and Transport in the Global Atmosphere: Emissions, Measurements and Models, edited by: Pirrone, N., and Mason, R., Springer, New York, 571-587, 2009.

Travnikov, O. and Ryaboshapko, A.: Modeling of mercury hemispheric transport and depositions, EMEP/MSC-E Technical Report 6/2002, 2002.

Travnikov, O., Ilyin, I., Pirrone, N., and Mason, R. (Eds.): The EMEP/MSC-E mercury modeling system, in: Mercury fate and transport in the global atmosphere, Springer, New York, NY, USA, 571-587, 2009.

Travnikov, O., Lin, C. J., Dastoor, A., Bullock, O. R., Hedgecock, I., Holmes, C., Ilyin, I., Jaegle, L., Jung, G., Pan, L., Pongprueksa, P., Ryzhkov, A., Seigneur, C., and Skov, H.: Global and Regional Modeling, in: Hemispheric Transport of Air Pollution. Part B: Mercury, edited by: Pirrone, N. and Keating, T., United Nations, 97-144, 2010.

UNEP Minamata Convention on Mercury, available at: http://www. mercuryconvention.org/, last access: 15 October 2014.

Urba, A., Kvietkus, K., Sakalys, J., Xiao, Z., and Lindqvist, O.: A new sensitive and portable mercury vapor analyzer GARDIS-1A, Water Air Soil Poll., 80, 1305-1309, 1995.

Vijayaraghavan, K., Karamchandani, P., Seigneur, C., Balmori, R., and Chen, S. Y.: Plume-in-grid modeling of atmospheric mercury, J. Geophys. Res., 113, D24305, doi:10.1029/2008jd010580, 2008.
Wang, Y., Huang, J., Hopke, P. K., Holsen, T. M., Rattigan, O. V., Chalupa, D. C., and Utell, M. J.: Effect of the shutdown of a large coal-fired power plant on ambient mercury species, Chemosphere, 92, 360-367, 2013.

Wang, L., Wang, S., Zhang, L., Wang, Y., Zhang, Y., Nielsen, C., McElroy, M., B., and Hao, J.: Source apportionment of atmospheric mercury pollution in China using the GEOS-Chem model, Environ. Poll., 190, 166-175, doi:10.1016/j.envpol.2014.03.011, 2014.

Weiss-Penzias, P., Jaffe, D. A., McClintick, A., Prestbo, E. M., and Landis, M. S.: Gaseous elemental mercury in the marine boundary layer: Evidence for rapid removal in anthropogenic pollution, Environ. Sci. Technol., 37, 3755-3763, 2003.

Weiss-Penzias, P., Amos, H. M., Selin, N. E., Gustin, M. S., Jaffe, D. A., Obrist, D., Sheu, G.-R., and Giang, A.: Use of a global model to understand speciated atmospheric mercury observations at five high-elevation sites, Atmos. Chem. Phys., 15, 11611173, doi:10.5194/acp-15-1161-2015, 2015.

Wright, G., Woodward, C., Peri, L., Weisberg, P. J., and Gustin, M. S.: Application of tree rings dendrochemistry for detecting historical trends in air $\mathrm{Hg}$ concentrations across multiple scales, Biogeochemistry, 120, 149-162, 2014a.

Wright, G., Gustin, M. S., Weiss-Penzias, P., and Miller, M. B.: Investigation of mercury deposition and potential sources at six sites from the Pacific Coast to the Great Basin, USA, Sci. Total Environ., 470, 1099-1113, 2014b.

Xiao, Z. F., Munthe, J., and Lindqvist, O.: Sampling and determination of gaseous and particulate mercury in the atmosphere using gold-coated denuders, Water Air Soil Poll., 56, 141-151, 1991.

Zhang, W., Tong, Y. D., Hu, D., Ou, L. B., and Wang, X. J.: Characterization of atmospheric mercury concentrations along an urban-rural gradient using a newly developed passive sampler, Atmos. Environ., 47, 26-32, 2012.

Zhang, Y., Jaeglé, L., van Donkelaar, A., Martin, R. V., Holmes, C. D., Amos, H. M., Wang, Q., Talbot, R., Artz, R., Brooks, S., Luke, W., Holsen, T. M., Felton, D., Miller, E. K., Perry, K. D., Schmeltz, D., Steffen, A., Tordon, R., Weiss-Penzias, P., and Zsolway, R.: Nested-grid simulation of mercury over North America, Atmos. Chem. Phys., 12, 6095-6111, doi:10.5194/acp12-6095-2012, 2012. 